\title{
Modelo vivo e arte - Tradições na modernidade
}

Living model and art - Traditions in modernism

\author{
Sergio Rizo
}

\section{RESUMO}

O papel da tradição e do ensino acadêmico no modernismo europeu, especialmente nas obras de alguns dos seus principais artistas, é um tema que não tem sido devidamente explorado nas pesquisas sobre arte. $\mathrm{O}$ artigo busca averiguar uma prática acadêmica fundamental, a do desenho do modelo vivo, no contexto da vida e da obra de Matisse e Picasso, dois representantes centrais e exemplares da vanguarda parisiense do início do século XX. Pretende-se ainda, com base na experiência do autor como professor de anatomia artística, abordar o ensino da anatomia e a sua relação com algumas obras referenciais do modernismo.

Palavras-chave: Modelo Vivo; Anatomia; Academias de Arte; Modernismo; Desenho; Matisse; Picasso.

\begin{abstract}
The role of tradition and academic teaching in European modernism, especially in the works of some of its leading artists, is a subject that has not been properly explored in art researches. This article seeks to investigate an essential academic practice, the drawing of the living model, within the context of the life and work of Matisse and Picasso, two central and exemplary representatives of the Parisian avant-garde of the early twentieth century. It is also intended, based on the author's experience as a professor of artistic anatomy, to approach the teaching of anatomy and its relation with some referential art works of modernism.
\end{abstract}

Keywords: Living Model; Anatomy; Art academies; Modernism; Drawing; Matisse; Picasso.

Arquiteto e Urbanista formado pela Universidade de Brasília (1979), mestrado em Fine Arts - Pratt Institute (1990), New York, como bolsista do Conselho Nacional de Desenvolvimento Científico e Tecnológico, CNPq e Doutorado em História pela Universidade de Brasília (2004). Professor da Faculdade de Arquitetura e Urbanismo da Universidade de Brasília, desde 2012, atualmente é Chefe do Departamento de Projeto, Expressão e Representação. Integra o Núcleo de Estética, Hermenêutica e Semiótica do PPG-FAU. Lecionou no Departamento de Artes Visuais/ Instituto de Artes da Universidade de Brasília de 1991 até 2012. Tem experiência na área de Artes, com ênfase em Pintura, Desenho, Anatomia Artística e Teoria e História da Arte. 
"Seria um engano pensar que houve uma ruptura na continuidade do desenvolvimento artístico desde o começo da pintura até os pintores contemporâneos. Abandonando a tradição, o artista conhecerá apenas um sucesso efêmero e seu nome logo será esquecido" ${ }^{1}$.

\section{Henri Matisse}

\section{O ENIGMA DO ABANDONO}

A utilização de modelos vivos nos seus desenhos de nus femininos é um fato bastante conhecido na biografia de Matisse. Algumas delas ultrapassaram o anonimato e seus nomes designam fases da vida e arte do pintor francês. Lydia Delectorskaya, a russa, por exemplo, sua modelo, assistente e companheira nos últimos anos de vida. Wilma Javour, a jovem húngara que posou para desenhos de notável expressão linear. Henriette, a musa atlética do seu mundo privado de luxo, calma e volúpia dos anos vinte, apenas citando essas três. Existem alguns registros fotográficos dessas sessões mostrando o método usual de Matisse, postado bem próximo das modelos, joelhos quase a tocar joelhos, com um olhar intenso e penetrante a registrar seus corpos em numerosos cadernos de estudos. A proximidade com que o pintor desenhava as suas modelos, claramente visível nos trabalhos produzidos, mostrou-se diferente e de certa forma inquietante, mesmo aos olhares dos anos cinquenta, década do falecimento do pintor ${ }^{2}$.

Matisse costumava dizer que conhecia muito o corpo humano e nunca escondeu o orgulho que sentia pelo seu profundo conhecimento da anatomia. Há um comentário seu sobre o envolvimento que teve com a arte do retrato e que demonstra os esforços dispendidos por anos a fio na apreensão da estrutura facial e corporal da figura humana ${ }^{3}$. Afirmava, ainda, que "Meus modelos, figuras humanas, nunca são figurantes num interior. São o tema principal de meu trabalho". 4

Curiosamente, o seu método de trabalho era começar o desenho observando o modelo vivo para, paulatinamente, abandoná-lo. $\mathrm{O}$ acontecimento chamou a atenção de Louis Aragon que o interpelou:

1 MATISSE, Henri. Matisse: Escritos e reflexões sobre arte, Cosac Naify, São Paulo, 2007, p.141.

2 Há duas observações interessantes relativas à proximidade com que Matisse desenhava as modelos, feitas por Françoise Gillot, sua amiga e esposa de Picasso: “Devido à miopia, trabalhava tão perto da modelo que sentia sua proximidade como uma parte viva do espaço pictórico. Longe de fazê-lo sentir-se ameaçado ou claustrofóbico, a presença da modelo guiava-o para uma transformação progressiva do que percebia para o que sabia ser verdadeiro, à medida que estendia a mão para atingir uma realidade duradoura nos domínios da arte". Françoise prossegue em outro trecho interpretando uma busca escultórica no olhar de Matisse: "Como anteriormente, ele continuava a trabalhar extremamente perto da modelo. Era como se os seus olhos estivessem roçando os volumes, em vez de simplesmente olha-los. Sem dúvida, precisava mais daquele sentido tátil do que só da percepção visual". In: GILOT, Françoise. Matisse e Picasso, Editora Siciliano, São Paulo, 1992, pp.172 e 178.

3 MATISSE, Henri.Op.Cit. p.197.

4 MATISSE, Henri. Idem.p.179. Cabe aqui um comentário a respeito de uma observação do crítico de arte norteamericano Clement Greenberg que erra feio no alvo quando afirma que "... as chances de pleno êxito de Matisse são muito maiores quando ele se mantém afastado da figura humana". In: Matisse Imaginação Erotismo Visão Decorativa, Sônia Salztein, Cosac Naify, São Paulo, 2009, p. 249. 


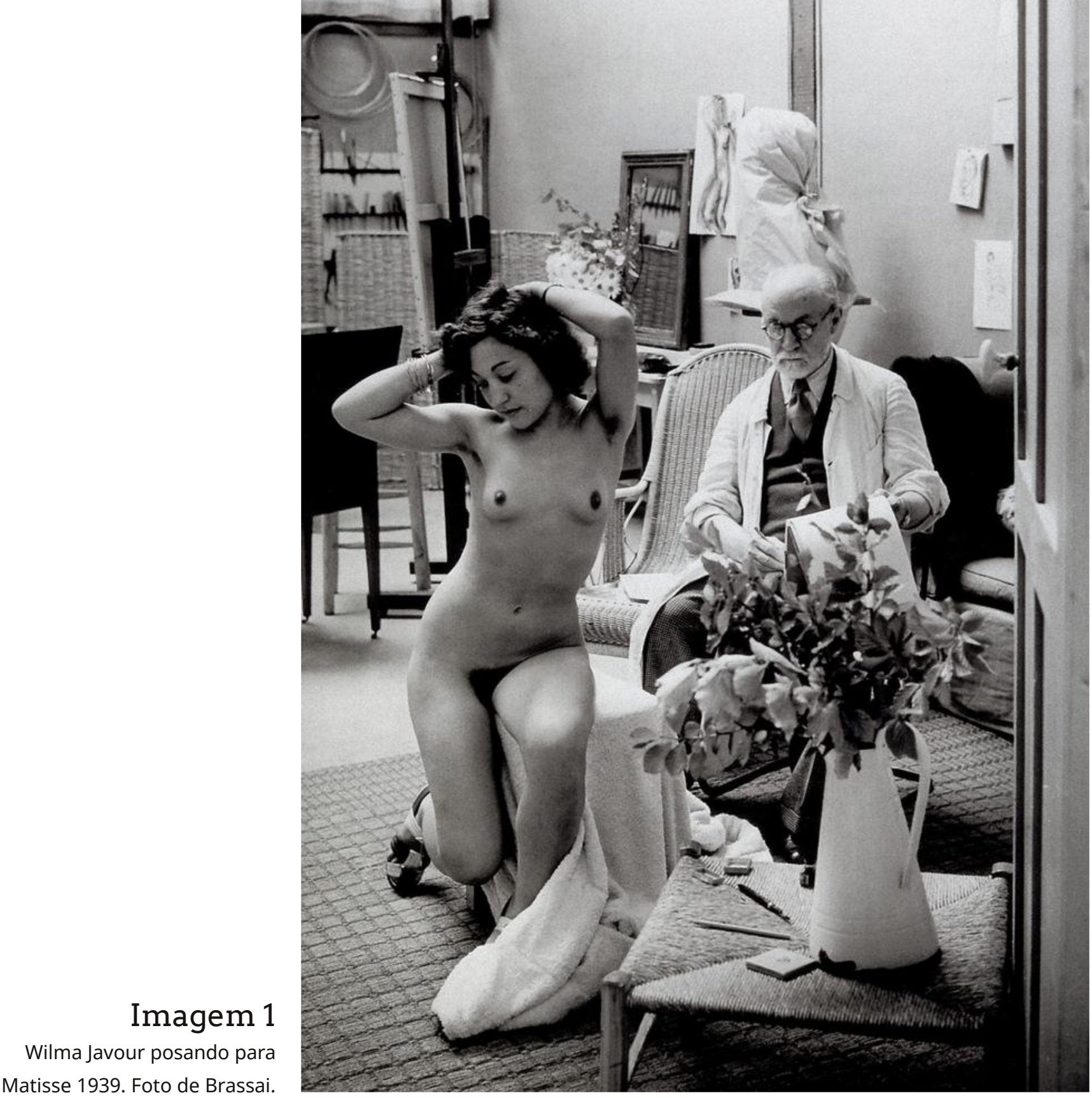

- Se desenhas a partir do modelo vivo, para que se afastar dele?

A resposta para essa pergunta, que é um dos objetivos do presente artigo, envolve uma

5 Ver o livro intitulado The Academy and French Painting in the Nineteenth Century, de autoria de Albert Boimes, 1971, que demonstra a importância da academia para todos os artistas do período, tanto os vanguardistas quanto os tradicionalistas. Ao publicar desenhos e pinturas produzidas nas academias do século XIX, preenche a lacuna deixada por Academias de Arte, Passado e Presente de Nikolaus Pevsner, relevante publicação, porém mais voltada para as questões da história institucional e da administração das academias. questão bem mais complexa do que uma simples escolha pessoal ou um problema de estilo de determinado artista. A solução do enigma que Aragon propôs com relação ao procedimento de Matisse e que o intrigou durante alguns anos, pode ser vislumbrada ao se considerar o contexto histórico em que Matisse teve a sua formação em arte e como ela influenciou sua vida profissional. Algumas pesquisas revisionistas recentes ${ }^{5}$ nos dão conta do papel da tradição acadêmica, especialmente no tocante a anatomia e ao modelo vivo, na arte de alguns dos mais importantes pintores da vanguarda europeia do princípio do século XX. 
O repúdio à Academia pelos modernos, especialmente ao ensino do desenho a partir do modelo vivo, foi só na palavra, como bem observa Goldstein ${ }^{6}$. Na realidade, Degas, Van Gogh, Seurat e Matisse "estenderam suas práticas do desenho do modelo vivo aos seus trabalhos da maturidade" 7 .

Tal fato é densamente exposto no imprescindível estudo de Goldstein ${ }^{8}$, que atualiza as discussões a respeito dos sentidos que o termo acadêmico assume no decorrer da história das Academias. Goldstein discute ainda o ensino da arte da Bauhaus confrontando-o com as práticas atuais do mundo da arte e do ensino universitário. Propõe, com argumentos convincentes, a paradoxal e compreensível existência de uma academia à la Josef Albers a partir do seu ensino no Black Mountain College. Traz à baila a incômoda questão da relação entre tradição e vanguarda expondo algumas interessantes contradições, desde o modernismo até a contemporaneidade. Por fim, coloca a pergunta crucial:

- O ensino ou a transmissão de conhecimento em arte pode acontecer sem uma tradição?

De qualquer maneira, a prática com o modelo vivo e os estudos da anatomia tiveram um papel relevante no ensino acadêmico, seja de forma efetiva ou pretendida, por quase cinco séculos de história.

No tocante à Matisse, o uso do modelo vivo, enquanto uma atividade feita a partir da observação da natureza indica uma atitude conservadora, fruto da prática acadêmica dos seus anos de formação. O próprio pintor declarou a Aragon que não havia cultivado o suficiente a memória das formas. Necessitava, portanto, desse estímulo inicial representado pela presença física da modelo, nem que fosse para dela se afastar posteriormente. Pode-se ainda divisar em tal procedimento uma permanência, tensa e diversificada que seja do pensamento clássico na modernidade, pois que este se centra nas representações do corpo humano. Tal fato nos indica outra parte da questão, também de caráter eminentemente histórico, em que esse afastamento da modelo se coloca frente à relação entre natureza e imaginação na arte do princípio do século XX.

Tomemos como exemplos, para efeitos de análise e contraste de seus métodos de desenho, dois artistas maiores, indispensáveis e que delinearam os principais rumos da vanguarda europeia no princípio do século XX, a saber, o já citado Henri Matisse e o espanhol Pablo Ruiz Picasso. Ambos possuem vasta fortuna crítica e são reconhecidos, entre outros aspectos, por suas propostas reformadoras da figuração humana.

\section{A CIÊNCIA HORRÍVEL DA ANATOMIA}

Science affreuse (ciência horrível), assim Ingres chamava o estudo de anatomia na Academia Francesa do século XIX. No entanto, o seu claro repúdio a essa prática convencional não significou uma posição hostil ao restante do ensino oficial. Muito pelo contrário, Ingres sempre demonstrou um autêntico fervor à estética acadêmica.

6 GOLDSTEIN, Carl. Teaching Art, Academies and Schools from Vasari to Albers. Cambridge University Press, NY, 1996. p. 180.

7 Idem. p. 180.

8 Idem. 
Era, por assim dizer, um dos seus campeões. As suas restrições eram relativas ao ensino da anatomia propriamente dito, feito com base numa literatura descritiva e segundo modelos de gesso e pranchas ilustradas representando os écorchés, as famosas figuras de escorchados. Dissecações propriamente ditas eram muito raras, mais por questões morais do que científicas. Ingres certamente concordava com isso, julgando desnecessário esse tipo de estudo. Porém, o seu conhecimento anatômico era invulgar a ponto de modificar, de acordo com um método expressivo próprio, as proporções de muitos corpos, principalmente femininos, nos seus desenhos e pinturas. As deformações e exageros anatômicos nas figuras de Ingres se tornaram peculiares e ele costumava dizer aos seus discípulos que um pescoço de mulher nunca era demasiado comprido na busca de um sentido particular de forma corporal. "Corrigir a natureza por meio dela própria" era a estratégia da sua visão plástica do corpo feminino. As pequenas verdades do detalhe paradoxalmente tão caras a Ingres, contradiziam o programa teórico acadêmico
Imagem 2 Estudos para O Banho Turco, por Ingres

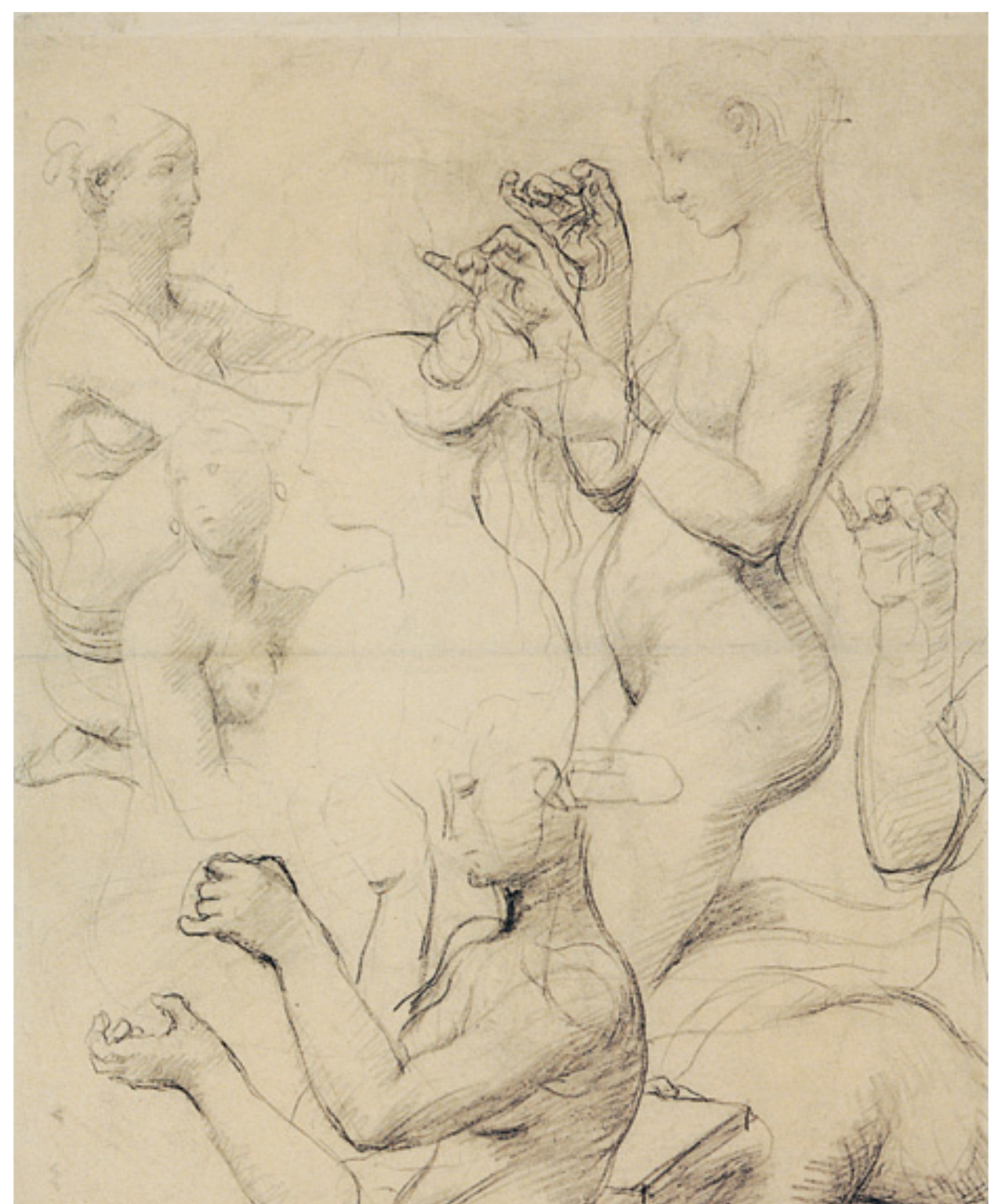




\section{Imagem 3}

A Dança, por Matisse (1910)

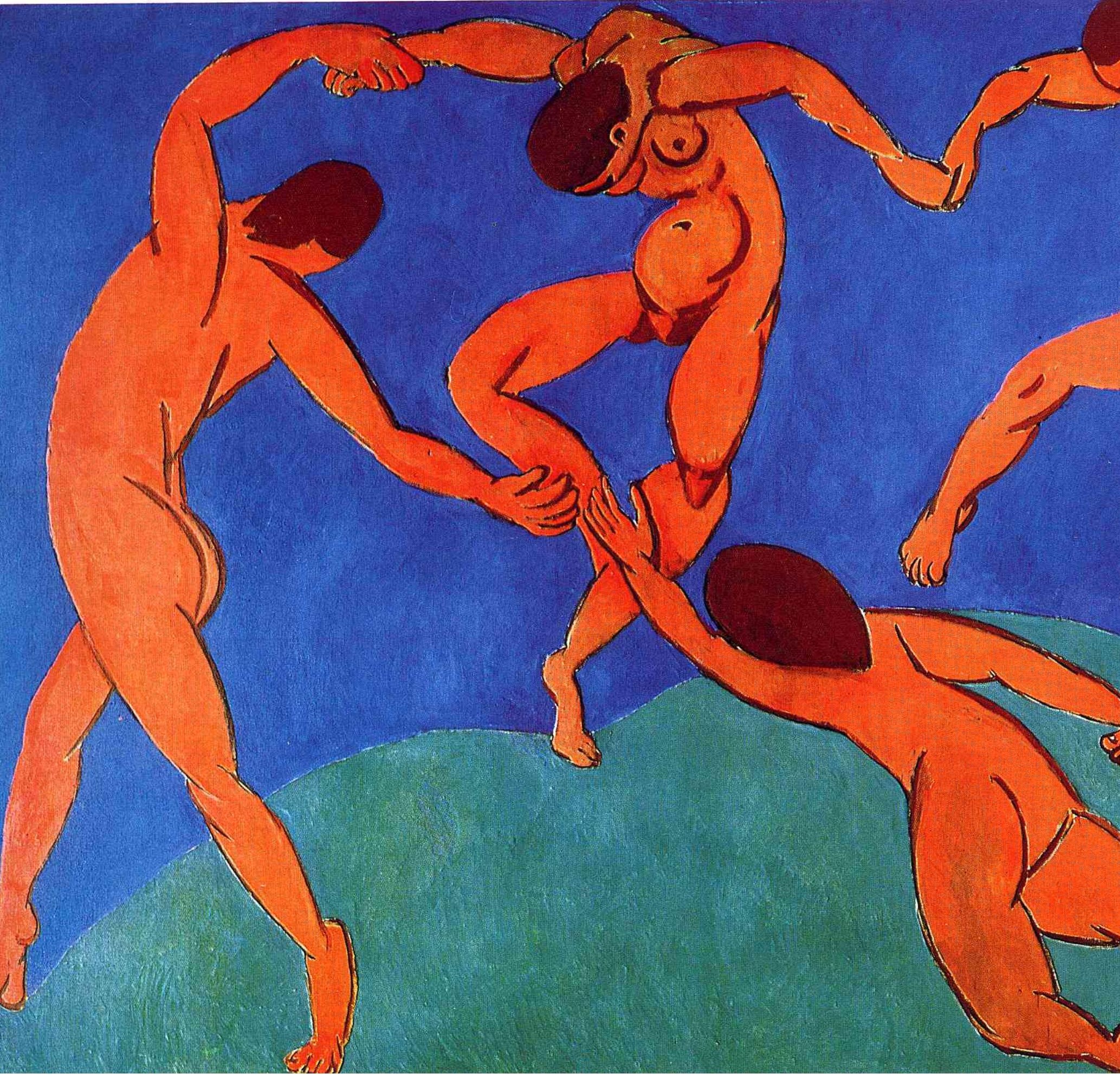




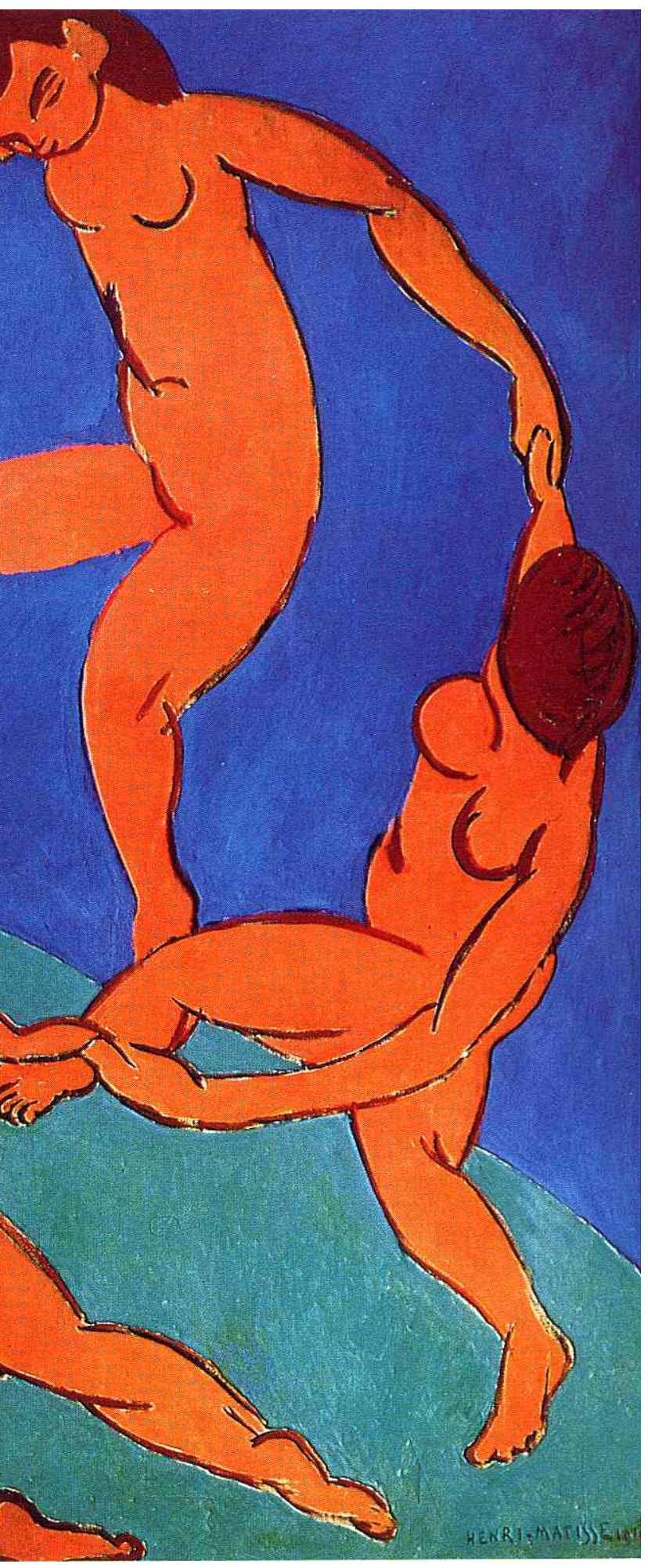

das generalizações, da regularidade, simplificação e das proporções estritamente matemáticas. Aliás, o legado de um ideal feminino de beleza que percorre a história, desde Praxíteles, passando por Boticelli, Giorgione, Ticiano, Rubens até o próprio Ingres, denota a observação arguta de Kenneth Clark quando este argumenta que... "o corpo feminino é, de um ponto de vista puramente plástico, mais rico quando for considerado apenas segundo uma disciplina abstrata”. ${ }^{9}$

Uma característica distinta em alguns apontamentos rápidos de modelos vivos de Ingres é a qualidade do desenho inacabado ${ }^{10}$. A incompletude confere uma urgência caracteristicamente moderna a esses trabalhos. São estudos, detalhes anatômicos de figuras que irão compor alegorias ou pinturas históricas, reunidas de forma mais ou menos improvisada em numerosas folhas de papel. Rodin e Matisse farão uso pleno desse recurso técnico nas suas improvisações performáticas dos desenhos das danças.

A tradição do uso quase que exclusivo de modelos femininos acentuou-se com Ingres. Invertendo o procedimento de Michelangelo no Renascimento, Ingres usava, com frequência, modelos femininos em substituição aos masculinos, ou seja, suas figuras masculinas derivavam das femininas. Tendo em vista a sua absoluta adesão à teoria estética de Winckelmann sobre a beleza feminina, aquela

9 CLARK, Kenneth. O NU, Um Estudo Sobre o Ideal em Arte, Editora Ulisseia, Lisboa, 1956, páginas 275-276.

10 Um exemplo destacado é o estudo para Livia em Virgílio Lendo a Eneida para Augustus, Octavia e Livia in: ARIKHA, Avigdor. Op. Cit. P. 42. 
referente à suavidade e continuidade das formas, Ingres foi o dirigente acadêmico responsável, em grande parte, pela substituição dos modelos masculinos pelos femininos na academia francesa, na segunda metade do século XIX. Até então, utilizavam-se quase que exclusivamente modelos homens. Ingres dá início, assim, a uma notória tradição de artistas da modernidade que fizeram das figuras de mulheres as representações características das suas obras, como Rodin, Degas, Gauguin e claro, Matisse e Picasso.

O conhecimento anatômico de Matisse é evidente na sua larga e variada produção de desenhos. Suas deformações anatômicas são o resultado lógico de um longo processo de decantação das formas femininas nos corpos das modelos que ele frequentemente desenhava. $\mathrm{O}$ fato é que, com poucas exceções, e mesmo nos seus nus mais experimentais do período inicial, como por exemplo, o $\mathrm{Nu}$ Azul de 1906, como também o Nu Cor-de-Rosa, do período posterior de 1935, as articulações mostram-se perfeitamente plausíveis no seu aspecto naturalista. E é o próprio Matisse que lembra o espanto de um médico, certa feita, ao ver seus desenhos e constatar o seu pleno domínio da anatomia das figuras. Mesmo quando Matisse compõe os espaços entre os corpos das suas figuras, como é o caso da segunda versão da Dança, de 1910, as sobreposições dos encaixes das articulações deixam transparecer o seu correto entendimento da anatomia. O espaço e as dançarinas mostram-se tão integrados que qualquer alteração nas suas posições comprometeria o todo do conjunto, arruinando por completo o tenso equilíbrio da composição.
Adicione-se o aspecto essencialmente plano e linear da pintura e tem-se uma proposição plástica que estabelece, no princípio do século $\mathrm{XX}$, uma interpretação caracteristicamente moderna de uma dança de bacantes ${ }^{11}$. Pode-se dizer aqui que a anatomia das figuras assume um papel estruturante da composição, ultrapassando a mera constituição do corpo no seu sentido de identificação do ser humano. Matisse, dotado de extraordinária intuição estética do todo, como bem observa Argan, transmuta aspectos anatômicos (as sobreposições musculares e as silhuetas tensionadas das figuras) num marcante elemento visual, ou seja, o arco convexo. Este, por sua vez, torna-se o princípio plástico tradutor da dinâmica dos corpos dançantes e da curva da terra (ou do mundo, no dizer de Argan) no movimento infinito de integração com o cosmos (note-se a conformação de uma lemniscata no grupo fechado das dançarinas). A curva do mundo é a mesma curva dos corpos que no seu êxtase evocam a metáfora do corpo terra, o mundo como um macro-antropos e o humano como um microcosmo, nessa gangorra de representações simbólicas. Certo está Kenneth Clark ao afirmar que "A arte moderna mostra, de forma mesmo mais explícita que a arte do passado, que o nu não representa simplesmente o corpo: Relaciona-o, por analogia, com todas as estruturas que se tornaram parte da nossa experiência imaginativa" ${ }^{12}$.

11 Segundo o constante no site da Tate Gallery atribui-se uma das referências da Dança como sendo uma ilustração de autoria de William Blake, intitulada de Oberon, Titania and Puck with Fairies Dancing, aquarela e Grafite s/ papel, 47,5 cm x 67,5 cm, de 1786, inspirada nos Sonhos de Uma Noite de Verão de William Shakespeare.

12 CARK, Kenneth. Op.Cit. p.286. 


\section{CORPOS CONVEXOS}

É interessante observar o predomínio quase absoluto das linhas convexas nos corpos das dançarinas. 0 próprio Matisse chegou a afirmar que "Toda forma do corpo humano é convexa, não se encontra nenhuma linha côncava". ${ }^{13}$ Do ponto de vista da moderna teoria da Gestalt a observação de Matisse procede, tendo em vista que uma das regras de Edgar Rubin afirma que a convexidade tende a predominar sobre a concavidade ${ }^{14}$. E foi Kenneth Clark, ainda, que designou um termo chave de ordem visual - o contorno cursivo, que facilita a condução do olhar para melhor se entender uma das funções que a linha cumpria nas representações dos corpos dançantes e orgíacos, numa das suas categorias fundamentais de análise do nu, o corpo em êxtase do tíaso, antiga dança processional grega.

Aqui se pode traçar um interessante percurso de legados formais que resultarão no corpo em arco de Rodin, em pleno século XIX, quando ele fala das características da arte grega de Fídias e

13 Anotações de Sarah Stein constante em Matisse, Escritos e reflexões sobre arte, nota de rodapé 42 na página 64.

14 ARNHEIM, Rudolf. Arte \& Percepção Visual, Enio Matheus Guazzelli \& Cia. Ltda. São Paulo, 1991, p.168.

15 Ibidem, p. 93.

16 Ibidem, p.48.

17 JUDRIN, Claudie. Rodin, 100 Drawings and Watercolours. Magna Books, Netherlands, 1990.

18 Disse Matisse, a respeito de sua visita à Rodin: “Tive a ocasião, certa vez, de ouvir os conselhos de Rodin a respeito de meus desenhos, que lhe foram apresentados por um amigo. Seus conselhos, porém, não me foram de nenhuma utilidade, e Rodin, naquela circunstância, mostrou apenas sua faceta detalhista". In Matisse, Escritos e Reflexões sobre Arte, p. 176. demonstra seu ponto de vista num rápido estudo por ele modelado, em perfil: "Este corpo está dobrado para trás; as costas estão cavadas e o peito levemente expandido. Numa palavra, a figura é convexa e tem a forma da letra C" ${ }^{15}$. Rodin prossegue e discorre sobre a beleza do corpo da mulher: “... o corpo humano dobrado para trás é como o jorro de uma fonte, como um belo arco no qual Eros ajusta as suas flechas invisíveis” ${ }^{16}$.

Não é mera coincidência, portanto, quando por seu turno, Matisse fala a respeito dos seus desenhos e da linha em arabesco, da curva e da sua busca dos signos visuais decorativos e universais, da mão em flor da arte birmanesa. Ora, Rilke ao comentar os desenhos das dançarinas cambojanas feitos por Rodin utiliza de uma linguagem poética, descrevendo a dinâmica das suas mãos ao executar os movimentos das suas danças orientais e termina por evocar e lhes atribuir uma imagem mágica como a das flores humanas ${ }^{17}$. 0 fato é que os desenhos lineares dos nus femininos de Rodin, particularmente os da sua última fase, exerceram uma considerável influência sobre Matisse, embora não claramente admitida por este nos seus depoimentos. Basta compará-los. Talvez o ressentimento se deva ao fato de que numa visita ao grande escultor com o fim de mostrar os seus desenhos, Matisse tenha se decepcionado com os conselhos recebidos ${ }^{18}$.

De qualquer maneira, o fascínio pelo movimento corporal feminino nos desenhos de ambos os artistas indica uma convergência de interesses, a dança, e lança uma nova luz nas representações da figura humana que se afasta das convenções acadêmicas da época. Existem semelhanças relevantes, inclusive, entre os 
métodos de desenhar de Matisse e Rodin. $\mathrm{O}$ escultor, na última etapa da sua vida, executou desenhos de modelos femininos nus de extraordinária rapidez e liberdade, onde as jovens moviam-se espontaneamente por entre os espaços do estúdio, sem assumir nenhuma pose particular solicitada pelo grande mestre. Na medida em que desenhava, Rodin ia largando as folhas de papel terminadas sobre 0 chão do estúdio e, a bem da verdade, não olhava sequer para o desenho que elaborava tamanha era a fixação da sua mirada na modelo ${ }^{19}$.

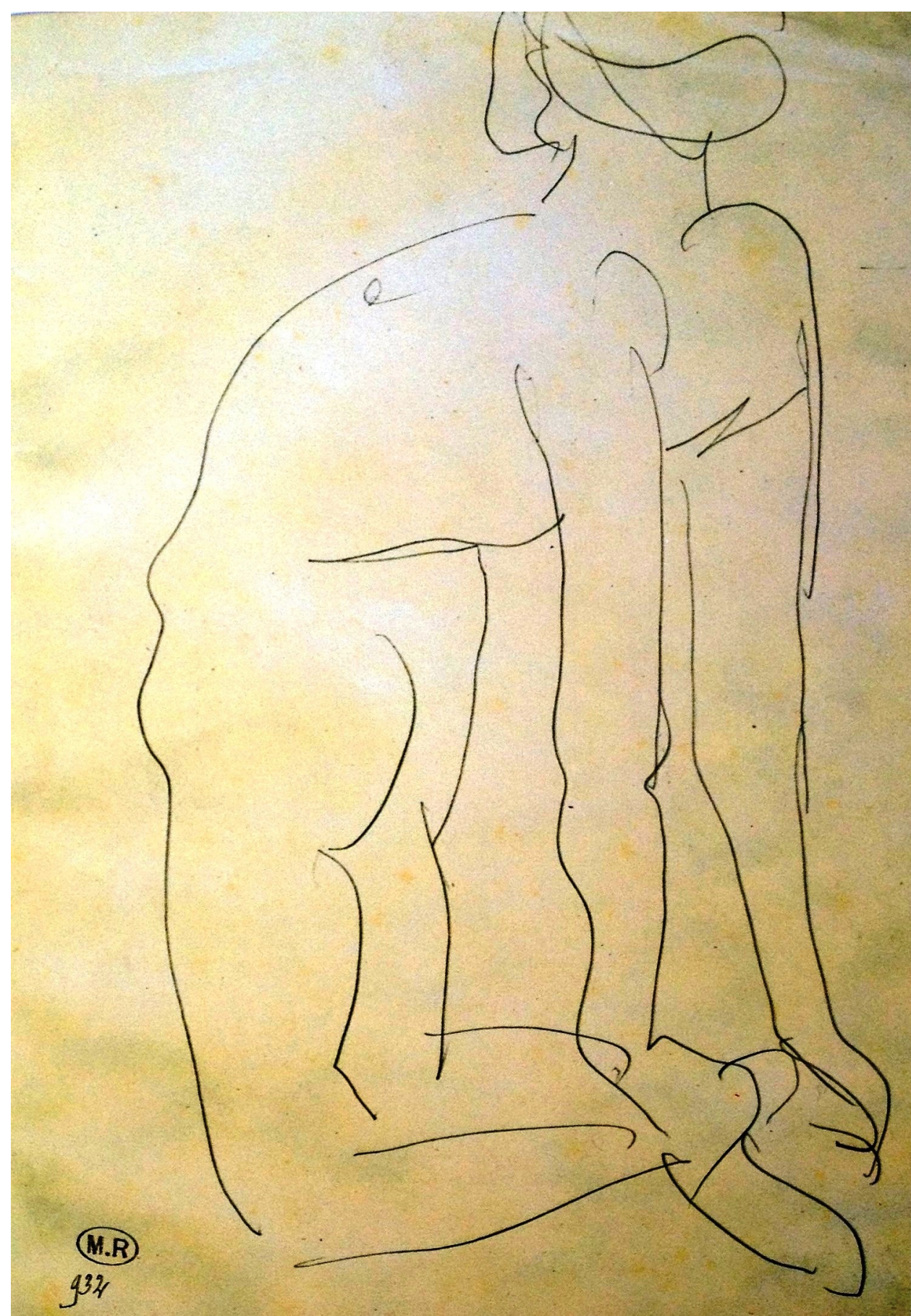

Imagem 4

Rodin (1912) 


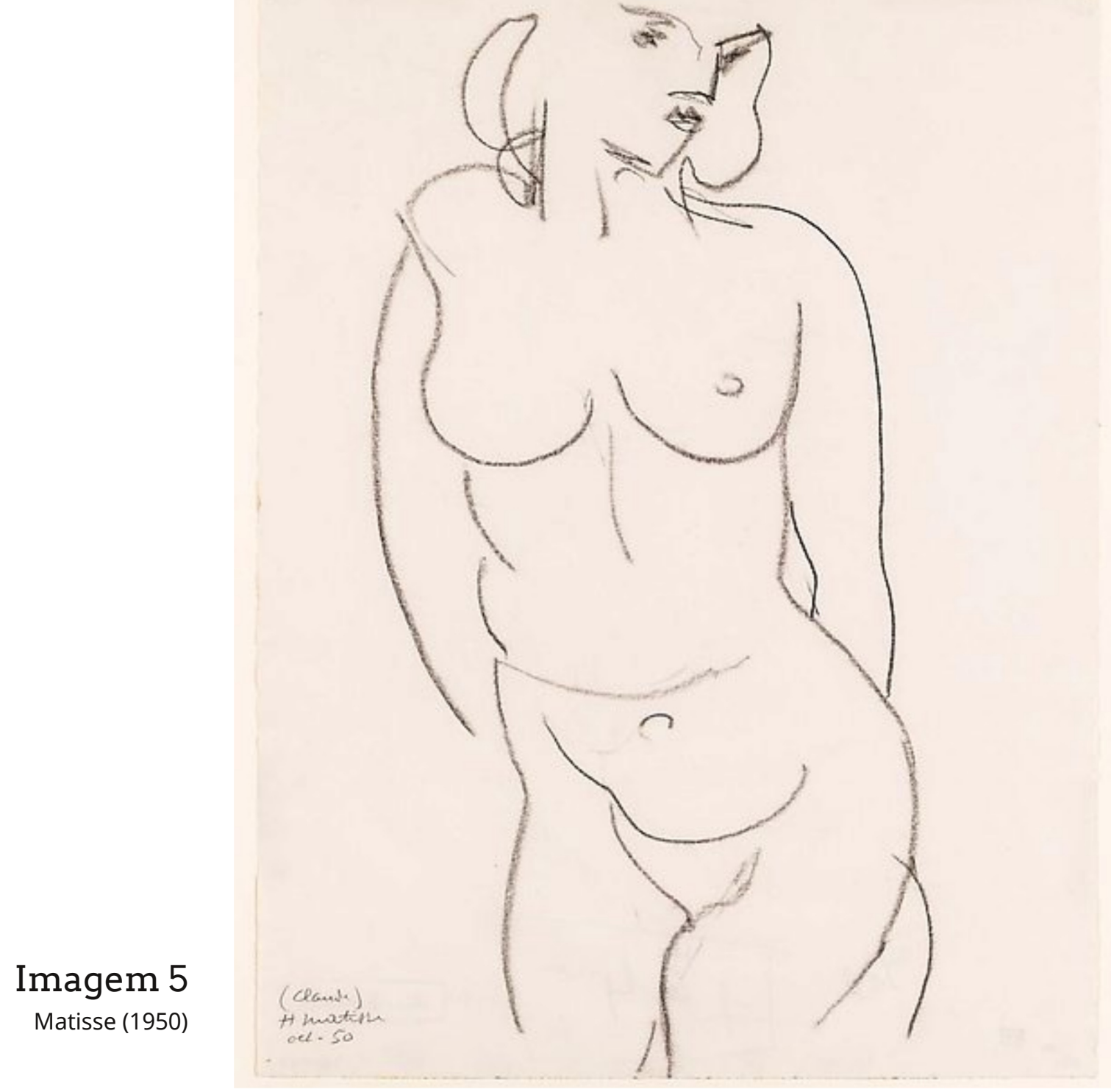

Matisse trabalhava de modo bastante parecido e a ligeira intensidade com que traçava as linhas no papel, sumariamente delineando os contornos dos corpos das modelos, tornava alguns desses desenhos de improviso quase que indistinguíveis daqueles feitos por Rodin. Além disso, os dois artistas também coincidiam a respeito da necessidade do conhecimento técnico na arte, quando Rodin chegou mesmo a dizer que:

“... A técnica é somente um meio. Mas o artista que a negligencia jamais atingirá seu fim, que é a interpretação de um sentimento, de ideias. Tal artista seria como o cavaleiro que se esqueceu de alimentar o seu cavalo"20.
Matisse, por sua vez, escreveu numa carta a Henry Clifford:

"As exposições que tive ocasião de ver nestes últimos anos me fazem temer que os jovens evitem a lenta e penosa preparação imprescindível a qualquer pintor contemporâneo que tenha a pretensão de construir apenas com cores", e completou a reflexão "Creio que o estudo pelo desenho é absolutamente essencial" ${ }^{21}$.

Sobre o signo do arco dos corpos dançantes de Matisse é crucial salientar que o seu conhecimento anatômico é que possibilitou esse salto qualitativo na síntese notável das suas formas na Dança.

19 RILKE, Rainer Maria. Auguste Rodin, Parkstone Press International, NY, 2011, p. 182.

20 RODIN, Auguste. Rodin on Art and Artists, Dover Publications, NY, 1983. p.45.

21 MATISSE, Henri. Op. Cit.,pp. 363-364. 


\section{O MOdELO ViVo E A ACADEMIA}

0 fundamento principal da prática acadêmica e a sua própria identidade institucional na história era o desenho da figura humana. De fato, o seu ensino constituía-se numa atividade convencional desenvolvida progressivamente a partir da cópia de modelos estatuários de gesso da antiguidade, dos desenhos dos grandes mestres do passado, dos catálogos de anatomia artística e das proporções do corpo e só então, no último estágio do processo de aprendizado e coroando a experiência, copiava-se o modelo vivo. Houve uma impressionante profusão desses catálogos anatômicos nas últimas décadas do século XIX, sendo o Cours de Dessin de Charles Bargue e Jean-Léon Gérôme um típico exemplo de uma publicação acadêmica de referência para o ensino do desenho nas demais escolas de arte e nos cursos preparatórios franceses. Dois outros importantes exemplos foram a Anatomie Artistique (1890) e Morphologie: la Femme (1920), ambos de autoria do Dr. Paul Richer, por muitos considerado como o pai da moderna anatomia artística. Os princípios acadêmicos da seleção cuidadosa, da simplificação das formas e do conhecimento da estrutura da figura humana refletiam a eficiência do seu sistema de ensino, que envolvia um método específico e de longo termo. 0 reconhecimento do estilo era definido pela clareza, contorno, simplificação geométrica e ritmo das formas. A Academia buscava promover, assim, a síntese entre o realismo acadêmico e o idealismo clássico.
Nesse contexto, tanto o uso do modelo vivo quanto o ensino da anatomia consistiram em práticas que resguardaram, em parte, certos procedimentos acadêmicos na arte da modernidade. Mesmo na Bauhaus alemã, considerada então uma escola da vanguarda com posturas pedagógicas inovadoras na arte e que pretendeu reformular muitas das convenções das academias do século XIX, ainda dominantes na Europa, foram utilizados modelos vivos. Oskar Schlemmer e Johannes Itten são exemplos de artistas e professores que utilizaram modelos vivos nas suas aulas na Bauhaus, uma prática então já considerada por muitos como sendo essencialmente acadêmica e, portanto, dispensável. Na verdade, Schlemmer foi mais longe ainda, pois segundo o constante no seu diagrama apresentado do Homem no Círculo das Ideias, na sua disciplina denominada O Homem, de 1928, ele incluiu o estudo da anatomia humana como um dos seus fundamentos. Por meio de uma investigação utópica e de noções científicas gerais estudava a figura humana, inclusive nas suas funções fisiológicas, integrando campos de conhecimentos interdisciplinares, em que figuravam a coreografia e a dança como interesses especialmente relevantes ${ }^{22}$.

O desenho do modelo vivo constituiu uma atividade que canalizou simultaneamente as três vertentes medulares da prática acadêmica, que eram o estudo da anatomia artística (a parte “científica”), a cópia a partir da natureza (o realismo acadêmico) e a memória da antiguidade (o idealismo acadêmico). Sendo assim, a Academia mostrou ser o principal

22 KUCHLING, Heimo. Oskar Schlemmer Man, The MIT Press, Cambridge, Massachussets, 1971, p.20. 


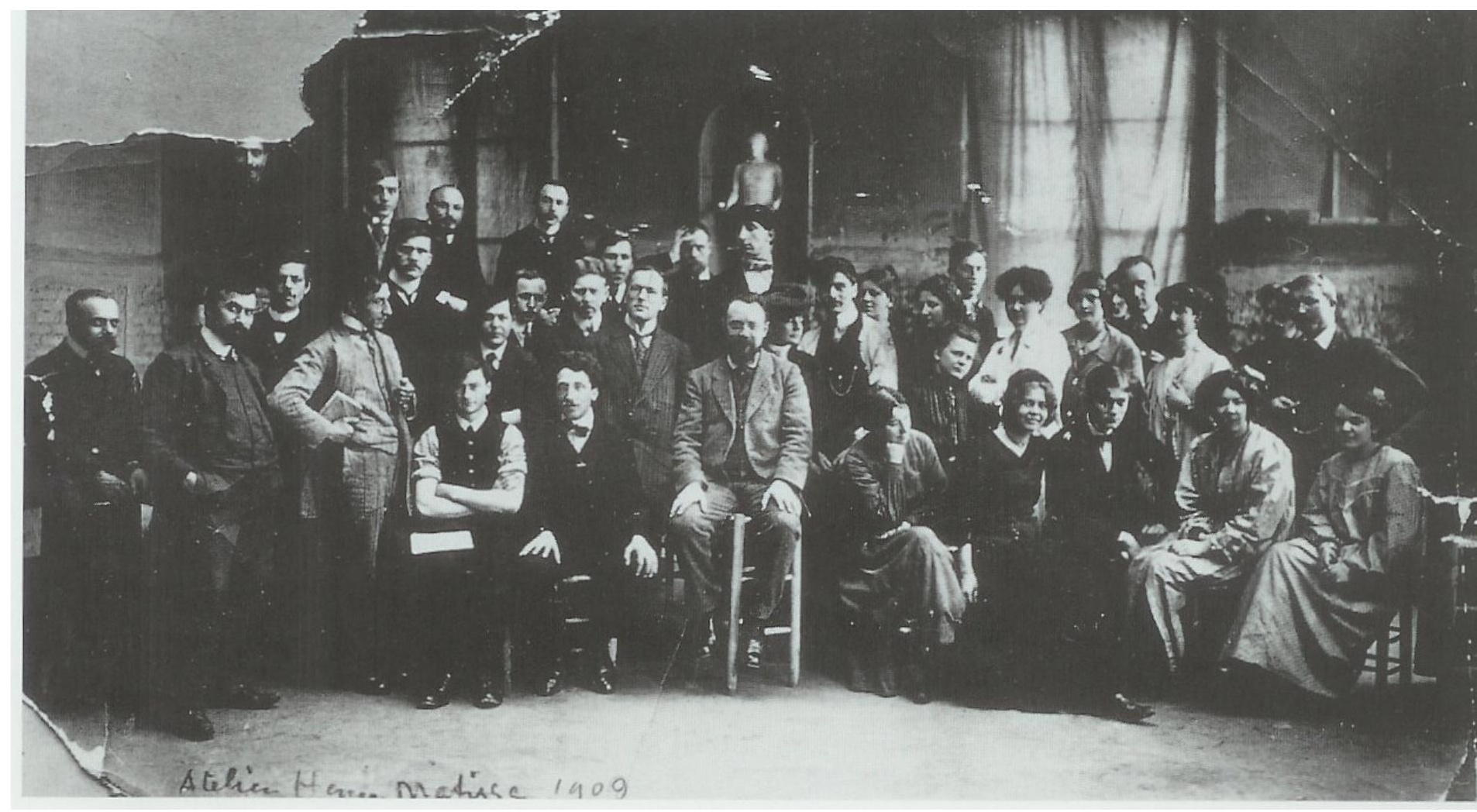

Imagem 6

Academia Matisse 1907-1909

agente promotor do pensamento que preconiza que a arte necessita da natureza como substrato e material a ser sublimado. Negou, portanto, a natureza comum não sujeita a regras, diante da qual a arte demonstra a sua superioridade. Assumiu, em última instância, a postura renascentista da arte como um processo de conhecimento da natureza a partir de princípios criados pelo homem, numa evidente superação da teoria mimética aristotélica. A beleza da arte é superior a da natureza e coube a Academia fomentá-la por meio da sua pedagogia.
Destarte, o uso do modelo vivo representou, de certa maneira, a perenidade desse pensamento essencialmente clássico na modernidade.

Significou, por assim dizer, uma espécie de reserva técnica, uma possibilidade, um meio de existir, daquelas representações corporais equilibradas e harmônicas e cujo caráter de permanência estampa um selo de qualidade que atravessa a história. Não mais apenas como um objeto estético de referência, mas como uma ideia, que conjuga, às vezes paradoxalmente, formas diferentes em tempos diversos, ressuscitando um sentimento 


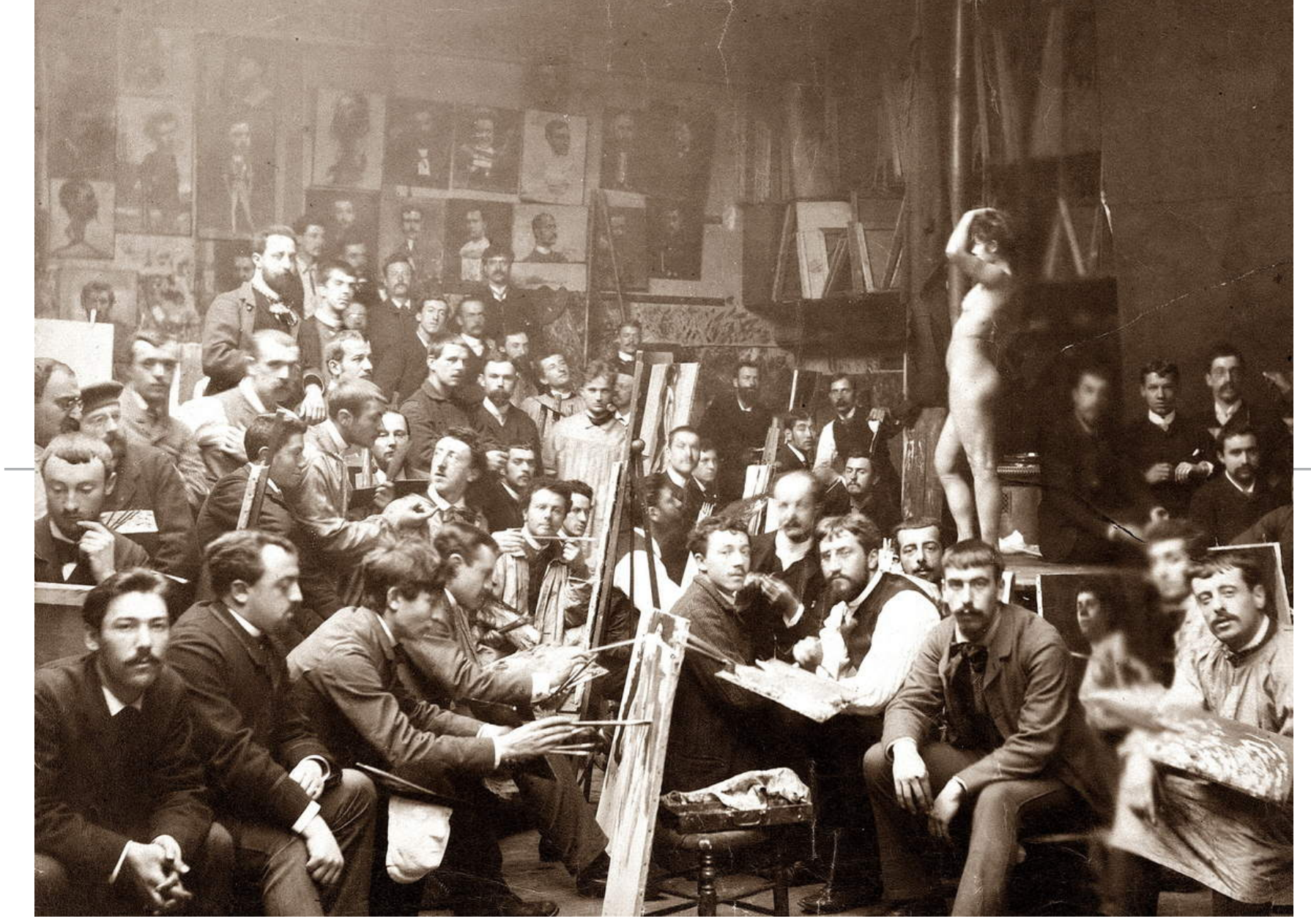

\section{Imagem 7}

Academia Julian, 1984

fundamentalmente clássico em sua natureza, que faz do corpo humano o centro das suas representações plásticas. Matisse e Picasso, cada um a seu modo e temperamento, não fizeram outra coisa a não ser reforçar esse ponto de vista nas suas obras que definiram os principais parâmetros da arte europeia da primeira metade do século XX.

O breve e concorrido período da docência de Matisse (1907-1909), como professor de arte da sua própria academia, o conscientizou da dificuldade de oferecer um ensino autônomo e moderno, radicalmente diferente do existente na Academia. Era necessária uma nova pedagogia para atender ao anseio vanguardista dos jovens aprendizes. Entretanto, a alternativa encontrada foi a de recapitular a sua própria experiência acadêmica, conforme o relatado por Goldstein ${ }^{23}$. Ao se confrontar com os primeiros trabalhos produzidos por seus alunos constatou decepcionado, que nada tinham a ver com sua obra e seu pensamento plástico. A contradição mostrou-se clara quando Matisse, logo a seguir, retornou com uma estátua antiga de uma cabeça grega e pediu aos alunos para desenhá-la. Depois disso, dispôs uma cópia de gesso do Apollo Piombino e outra de um escravo de Michelangelo. Por fim, os fez desenhar e pintar a partir do modelo vivo. Exatamente o método acadêmico que ele considerava mortal para os jovens artistas! Incapaz de transformar seus carneirinhos em leões ${ }^{24}$, Matisse provavelmente se deu conta da impossibilidade de se ensinar arte, salvo aquelas técnicas que havia aprendido na Academia. Desistiu então das atividades letivas, dedicando-se integralmente a sua arte ${ }^{25}$. Sua

23 GOLDSTEIN, Carl. Op. Cit. P. 73. 24 MATISSE, Henri. Op. Cit. P. 117.

25 Sua desistência decerto não ocorreu sem algumas reflexões a respeito, como naquela que diz: "Um atelier de alunos me faz lembrar A parábola dos cegos de Bruegel, em que o professor, o primeiro cego, conduz os outros que o seguem". In: MATISSE, Henri. Op. Cit. P. 176. 
desistência indica a problemática que prevalecerá, a partir do início do século XX, nas discussões pedagógicas da arte, frente às mudanças ocorridas com o advento do modernismo, principalmente em relação aos métodos tradicionais de ensino das academias.

26 Tradução livre: "Décomposer les éléments d'un sujet, pour le recomposer dans un systèm d'abstraction".

*Parêntese meu.

\section{A IRONIA - PICASSO \\ E O IDEAL ACADÊMICO}

Se entendermos essa relação ao pé da letra e de forma irônica, Picasso seria o resultado extremado do impulso idealizador da Academia, levando às últimas consequências o estipulado "Decompor os elementos de um tema (podendo ser a figura humana*) para recompô-los segundo um sistema de abstração” de Quatremère de Quincy ${ }^{26}$. Evidentemente, Picasso recompõe suas

Imagem 8

Matisse (1936)

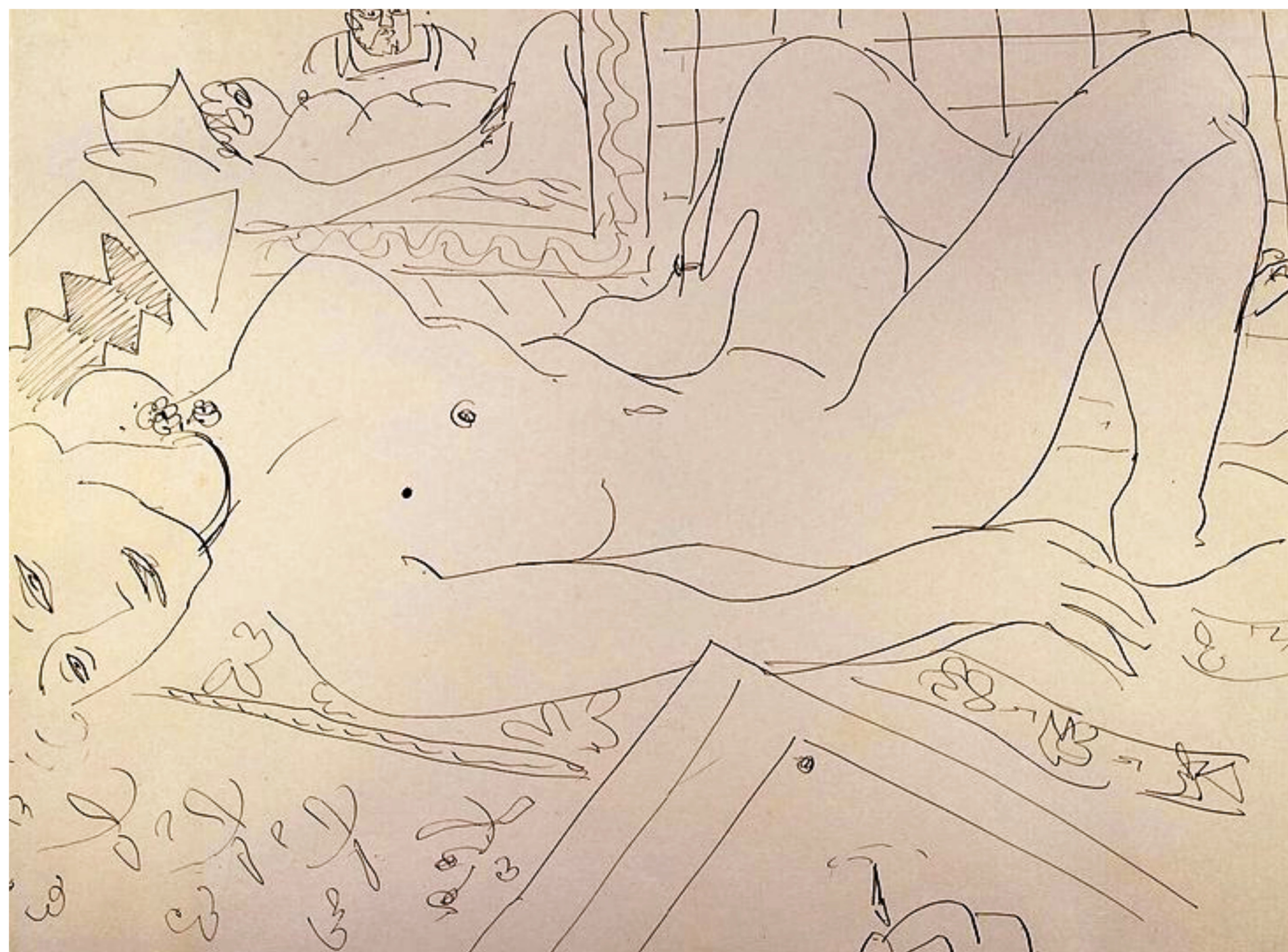




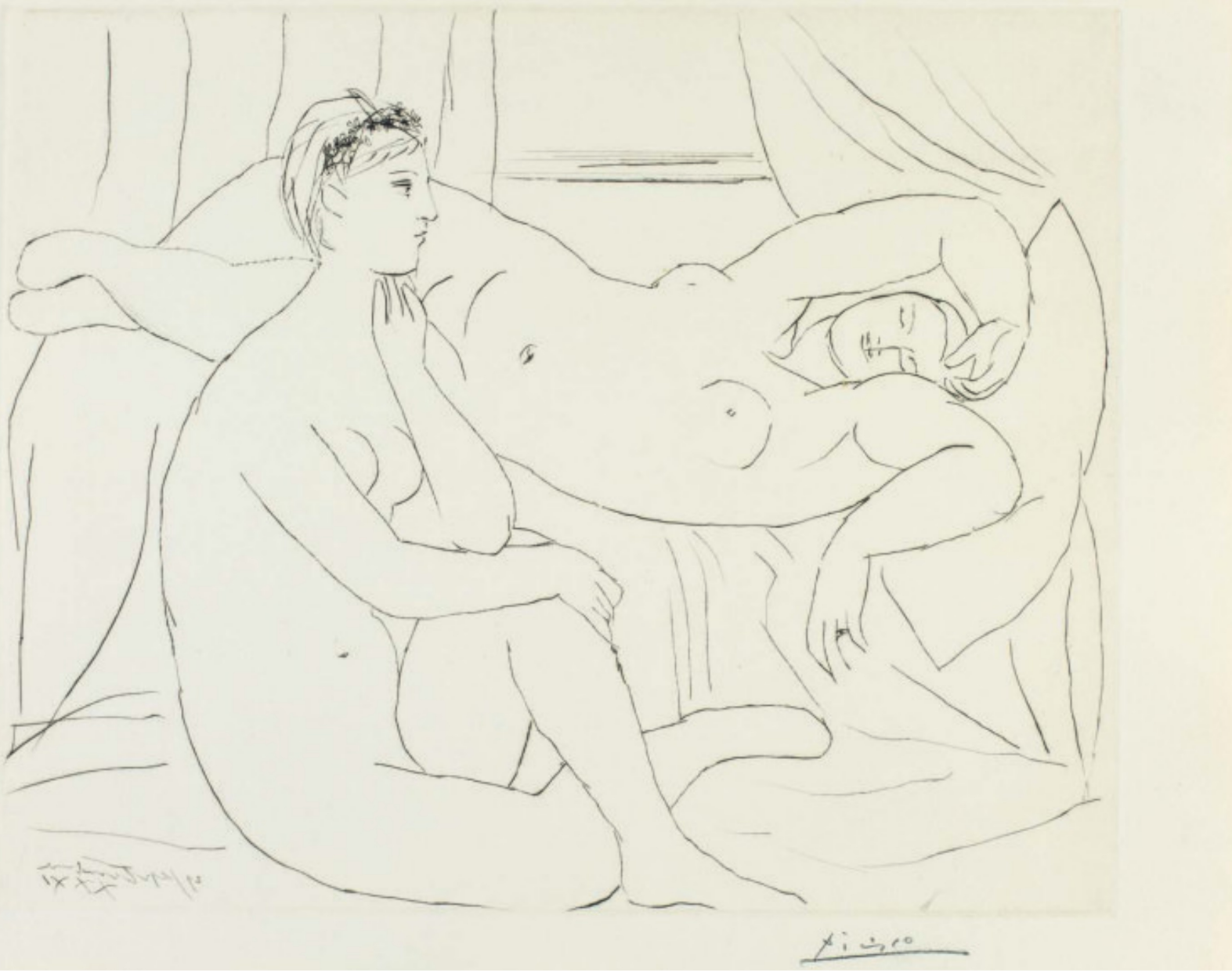

\section{Imagem 9}

Mulheres Repousando, Suite Vollard, por Picasso (1933)

figuras segundo uma idealização intelectualizada e própria, concernente a um sentimento corporal posterior aos seus experimentos da vanguarda cubista e dissonante em relação às representações vigentes na Academia. Mas a insistência no nu feminino é a mesma. E o rigor compositivo, assim como o privilégio dispensado ao universal sobre o particular, também.

Ainda de acordo com o receituário neoclássico de Quatremère de Quincy ${ }^{27}$, de criar figuras imaginárias imitando a natureza sem o modelo, as personagens de Picasso, notadamente as das ilustrações das Metamorfoses de Ovídio e as da Suite Vollard, seriam assim como que traduzidas num filtro da modernidade, feitas para aquelas sensibilidades educadas nas referências da fragmentação ${ }^{28}$, da deformação ${ }^{29}$, no aspecto plano das pinturas e, sobretudo, no crescente processo de simplificação das imagens na
27 Aqui cabe uma citação do próprio Quatremère relativa à figura, tema dominante da poética neoclássica: “O tipo é a constante em relação à qual podem e devem se realizar variantes específicas, que modificam sua forma, mas não sua estrutura". In: ARGAN, Giulio Carlo. A Arte Moderna na Europa. P.235.

$28 \mathrm{Um}$ interessante contraponto ao culto moderno do fragmento: “Um falso aspecto da arte moderna nasce dessas transformações involuntárias da arte antiga: a Psique do Museu de Nápoles, com o crânio cortado por uma pancada, cindido horizontalmente, tem ar de um Rodin; um torso decapitado voltando-se sobre seu pedestal faz pensar num Despiau ou num Maillol. O que os nossos escultores imitam por desejo de abstração, com auxilio ademais de um hábil artífice está aqui intimamente ligado à aventura da própria estatua". In: YOURCENAR, Marguerite. O Tempo, Esse Grande Escultor, Editora Nova Fronteira, RJ, 1985. P. 109.

29 Há um comentário esclarecedor a respeito da necessidade formal das deformações de Picasso feito por Ross Neher: "As distorções são determinadas pela concepção geral da obra; sua arte não contradiz a lei fundamental da consistência interna da mesma". In: NEHER, Ross. Van Gogh and the Problem with Tradition, Arts Magazine, January 1989, p.45. (Tradução minha). 
emergência do século XX. É oportuno destacar que "O próprio Cubismo têm sido chamado de Platônico na medida em que envolve uma investigação da natureza essencial das coisas"30.

Seguindo esse raciocínio, Guernica, considerada por muitos como a obra máxima de Picasso, seria a última e grandiosa pintura de história ${ }^{31}$, categoria maior de acordo com a classificação ${ }^{32}$ da Academia. Alguns dos seus atributos formais tais como a composição em um plano só, bem ao estilo da procissão ${ }^{33}$, a redução das figuras aos signos simbólicos (sem modelos, portanto) e das cores ao preto, branco e cinza, remeteriam ao receituário da estética neoclássica e aos anseios de grande parte dos jovens artistas da época de Ingres.

30 GRAFTON, Most \&Settis. Op. Cit. p.727.

31 ARIKHA, Avigdor. Op. Cit. p.10.

32 Codificação dos gêneros pictóricos de acordo com a nobreza do tema e segundo Félibien des Avaux: Em primeiro, a composição alegórica (o fim supremo da pintura). Em segundo, a pintura de história. Em terceiro, o retrato. Em quarto, as ações comuns dos homens. Em quinto, a paisagem com seres vivos. Em sexto, a paisagem pura. Em sétimo e último, a natureza-morta. In: GUINSBURG, J. Op. Cit. p. 271.

33 Princípio adotado pela escola de Jacques-Louis David, pintor neoclássico francês, que chegaria ao fim, de acordo com Arikha, com o aparecimento da Apoteose de Homero de autoria do seu compatriota e discípulo Ingres. In: ARIKHA, Avigdor. Op.Cit. P. 10.

34 GILOT, Françoise. Matisse e Picasso, Editora Siciliano, SP, 1992.

35 GILOT. Op. Cit. p.179.

36 STEIN, Gertrude. Picasso, Editora Âyiné, BH, 2016. P. 15 37 De acordo com Warncke: “Este método permite, como nenhum outro, dar a forma específica dos objetos. Com efeito, só aquele que observou perfeitamente o motivo e sabe impregnar-se de todas as proporções formais assimilando-as e concebendo-as com precisão está em condições de desenhar um tema no impulso de uma só linha". In: WARNCKE, Carsten-Peter. Pablo Picasso 18811973, TASCHEN, Köln, 2002, p. 39-40.
Françoise Gillot escreveu, no seu relato biográfico de Matisse e Picasso ${ }^{34}$, que dos vários retratos que o seu marido fez dela, quase nada foi de observação e sim de memória e imaginação. Escreve ainda que posou para Picasso somente uma tarde em toda sua vida. Um traço particular que diferenciou o espanhol do francês visto que Picasso utilizou pouquíssimas pessoas para posar, enquanto Matisse necessitava frequentemente de modelos como trampolins de partida ${ }^{35}$.

$\mathrm{Na}$ introdução do seu ensaio sobre Picasso, Gertrude Stein bem resume a utilização de modelos vivos nas academias francesas novecentistas e seu posterior desuso na modernidade: "No século XIX os pintores descobriram a necessidade de sempre ter um modelo diante de si no século XX descobriram que nunca deviam olhar para um modelo" ${ }^{36}$. A citação ilustra de maneira clara o método usual de Picasso de trabalhar as representações dos retratos e dos corpos femininos a partir da sua memória e imaginação.

A formação artística de Picasso foi primordialmente acadêmica, de uma precocidade que não era tão incomum assim para a época e o contexto cultural em que ele viveu. Cursou a escola de arte "La Guarda", na Corunha em 1892, que seguia os preceitos didáticos da Academia Real de Madrid. Três anos mais tarde ingressa na Escola de BelasArtes de Barcelona e finda seu aprendizado em 1897. A compenetração recorrente de Picasso com a estatuária antiga, bem como com os temas relativos à mitologia greco-romana já datam, provavelmente, do seu período inicial de formação em arte. No aspecto formal das técnicas e métodos escolares apreendidos, cabe registrar o desenho de um traço ${ }^{37}$ e o 
esquematismo da assimilação acadêmica da realidade ${ }^{38}$, sendo este último a pedra angular do trabalho pictórico de Picasso, como bem observado por Warncke ${ }^{39}$.

Picasso foi um adepto típico daquele sentimento perene da Arcádia, tendo em vista o seu profundo conhecimento da literatura antiga e da mitologia greco-romana. No decorrer da sua duradoura carreira a temática dos paraísos pastoris aflorou sempre que surgiu a necessidade de um redirecionamento ou de uma mudança na sua arte. A Arcádia, enquanto temática representava, por assim dizer, o seu porto seguro, um local onde ele recuperava 0 folego para a sua contínua e incessante jornada de transformações e experimentos formais e conceituais. Equivalia ao interlúdio dentre as várias fases da sua vasta produção. Essas retomadas cíclicas duma figuração mais explícita também significaram a sua recusa em assumir uma direção mais notadamente abstrata na sua arte ${ }^{40}$.

Nesse particular, os “clássicos” de Picasso representaram, segundo Lisa Florman, verdadeiros desafios aos paradigmas modernistas da evolução artística ${ }^{41}$. Nas suas séries de gravuras essencialmente lineares, a saber, As Metamorfoses de Ovídio de 1930 e a Suíte Vollard de 1933, Picasso contrariou a noção de progresso em arte no tocante ao estilo e afirmava, com relação à evolução da sua arte "Para mim não há nem passado e nem futuro na arte. Se uma obra não estiver viva sempre no presente não deverá ser considerada” ${ }^{42}$. Seu processo de trabalho preconizava que diferentes temas inevitavelmente requeriam métodos diferentes de expressão. Tal postura não implicava nem em evolução ou progresso, mas numa adaptação da ideia que se queria expressar e o modo de expressá-la. O vasto campo da história da arte oferecia a oportunidade de uma livre atuação do artista, tanto em termos formais quanto conceituais. O tempo do presente passou a ser o agente unificador dessa operação ${ }^{43}$. De acordo com Argan:

38 “Este esquematismo consiste em reduzir num primeiro tempo o objeto a reproduzir a um pequeno número de tramas geométricas fundamentais. O tema representado passa então a uma nova configuração mediante um trabalho ainda mais acabado do contorno, para só ser modelado em última instancia em todas as suas partes". In: WARNCKE, Carsten-Peter. Op. Cit. p. 40. 39 WARNCKE, Carsten-Peter. Picasso, Taschen, Köln, 2002, p. 40.

40 Cabe aqui uma observação feita por Rudolf Arnheim respeitante ao processo de abstração predominante na arte moderna da segunda metade do século XX: "Considerando o lado negativo, a elevada abstração arrisca-se a separar-se da riqueza da existência real. As grandes obras de arte e da ciência evitaram sempre esta limitação; elas abarcaram a série toda da experiência humana aplicando formas ou princípios mais gerais para as maiores variedades de fenômenos. Consideraremos apenas a abundante variedade de criaturas que um Giotto, um Rembrandt ou um Picasso subordinam aos princípios gerais que determinam sua visão da vida e, portanto, seu estilo. Quando se perde o contato com uma serie ampla de experiências humanas, não resulta arte, mas jogo formalístico com formas ou conceitos vazios". In: ARNHEIM, Rudolf. Arte e Percepção Visual, Livraria Pioneira Editora, São Paulo, 1991, p. 137.

41 FLORMAN, Lisa. Myth and Metamorphosis, Picasso's Classical Prints of the 1930's, The MIT Press, Cambridge, MA, 2000.

42 FLORMAN, Lisa. Op. Cit. P. 3.

43 "Se de fato houve um princípio orientador dentre a variedade caleidoscópica com que Picasso abraçou o passado clássico, este foi a visão Nietzscheana da experiência Grega como uma combinação incendiária dos espíritos Apolíneos e Dionisíacos, uma ideia muito discutida nos círculos da avant-garde frequentados por Picasso quando jovem". In: GRAFTON, Most and Settis. Op.Cit. P.727. 
"Em sua concepção, a arte não é antecipação do futuro, como queriam as vanguardas, nem evocação do passado, como queriam os tradicionalistas; é presente absoluto, talvez a única maneira para dar realidade e forma ao presente, que para Bergson era o instante inapreensível, para não dizer inexistente, em que o futuro vira passado" 44 .

\section{"Classicismos" FRANCESES}

\section{Antiguidade clássica é um termo} congestionado de visões de mundo diversas ao longo da história, indicadoras das múltiplas diacronias existentes nas sempre tensas relações entre o presente e o passado. 0 contato visual direto com os monumentos escultóricos atenienses antigos ocorreu somente no decorrer do século XVIII. Antes disso, os modelos de concepções culturais da antiguidade grega foram as cópias escultóricas romanas descobertas e escavadas na Cidade Eterna e no ocidente. 0 sentido de "clássico" nesse artigo relacionase, principalmente, às duas vertentes culturais existentes em Paris no final do século XIX e início do século XX: as visões da Arcádia e o classicismo acadêmico.

As visões utópicas dos paraísos primitivos das Marquesas e do Tahiti, assim como a Arcádia grega e a Idade de Ouro foram representações significativas de um classicismo vigente entre os pintores e escritores de Paris no século XIX. De fato, a temática clássica da Arcádia permeou

44 ARGAN, Giulio Carlo. A Arte Moderna na Europa de Hogarth a Picasso, Companhia das Letras, São Paulo, 2010, p.592.

45 ARGAN, Giulio Carlo. Op. Cit. p. 589.

46 GOLDSTEIN, Carl. Op. Cit. P. 156. uma parte significativa da produção de arte até mesmo da vanguarda parisiense. Matisse, o fauve, impôs-se no panorama artístico da cidade luz com a sua tela A Alegria de Viver, de 19051906, um banho de luminescências douradas sobre corpos exaltantes do paraíso pastoril que nas palavras de Argan... "marcava a fusão triunfal, para não dizer a identificação, de classicismo e impressionismo - enfim: a reivindicação da grande e universalista tradição clássica da cultura francesa” ${ }^{45}$. Ainda de acordo com Argan, essa mesma tradição cultural francesa (o clássico-moderno dos fauves) sob o signo mediterrâneo do classicismo se opôs à tradição alemã (o romântico-moderno do Die Brücke) sob o signo nórdico do romantismo. Com efeito, pesquisas recentes apontam o interesse da vanguarda parisiense num novo classicismo que diferiu do antigo por sua preferência pela arte Grega arcaica do século VI A.C. Um aspecto diferente digno de menção foi o repúdio da vanguarda parisiense à estética de Winckelmann. A rejeição ficou patenteada na declaração de Guillaume Apollinaire:

"Os estetas e pintores alemães inventaram o academicismo, aquele falso classicismo contra o qual a arte verdadeira vem lutando desde Winckelmann, cuja influência perniciosa nunca pode ser exagerada. Todo crédito deve ser dado à escola francesa por essa oposição; as inovações audaciosas dos pintores franceses ao longo do século XIX foram, acima de tudo, um tremendo esforço no sentido de redescobrir a autêntica tradição da arte" ${ }^{46}$.

A raiz literária da sobrevivência de longo termo da Arcádia encontra-se em Virgílio, o transfigurador de uma região montanhosa e remota da Grécia num reino imaginário de 
perfeição e felicidade, constante nas suas obras, mais especificamente nas Éclogas ${ }^{47}$. A mistura de idealismo, nobreza e melancolia das Éclogas atraiu tanto os poetas clássicos como os simbolistas franceses na segunda metade do século XIX. Victor Hugo, Charles Baudelaire e Stéphane Mallarmé são escritores que comungaram a mesma afeição pelas visões arcádicas. Estas, por sua vez, serviram de referência para muitos integrantes do meio cultural parisiense, como diversos pintores da vanguarda, entre eles Matisse. Ele ilustrou, por exemplo, a edição de 1932 do livro As Poesias de Mallarmé e também a edição de 1947 do livro As Flores do Mal de Baudelaire.

Outro fator favorável à vigência do tema arcádico no meio artístico parisiense foi a sua consonância com a ideologia política da Terceira República (1870-1940), que era o modelo dos valores morais franceses, de notável elevação lírica, segundo o Classicismo como fonte da sua identidade cultural ${ }^{48}$. Tal contexto possibilitou a encomenda de murais públicos, por parte do governo francês e Puvis de Chavannes, pintor de evidentes tendências clássicas, recebeu a encomenda de dois painéis monumentais com os temas da paz e da guerra. A obra de Puvis mostrou ser um modelo claro e ideal da Arcádia pastoril que, por um lado, nutriu as expectativas de uma classe burguesa ansiosa pelo “clássico” idealizado e, por outro, significou uma obra de referência para uma vanguarda sedenta de uma visão paradisíaca primitiva, que se opunha, de certa forma, ao avanço inexorável da revolução industrial.

\section{A Academia francesa do ancien régime foi} extinta por lei durante a revolução em 1793, principalmente por razões políticas. Em 1795, foi recomposta em duas partes, atreladas ao Instituto da França: a Academia de Belas Artes, responsável pela administração (e contratação de professores e supervisão dos concursos) e a Escola de Belas Artes, voltada para o ensino propriamente dito. Nesse modelo, a Escola funcionava como um centro "avançado" de artes recebendo principalmente os alunos previamente instruídos nos princípios básicos nos ateliers particulares de seus acadêmicos. Embora o seu currículo incluísse o desenho a partir dos modelos de gesso e dos modelos vivos, assim como o estudo da anatomia e da perspectiva, a prática principal visava sobretudo os concursos de arte.

Essa relação irá permanecer praticamente inalterada até a reforma do seu ensino de 1863, ano em que a Escola Superior de Belas Artes de Paris passa a encampar, como seu programa oficial e nas suas dependências as atividades da pintura, escultura e arquitetura, que até então aconteciam quase que exclusivamente nos ateliers particulares. Foi justamente num desses ateliers particulares, o de Gustave Moreau, que Matisse teve a sua formação em arte ${ }^{49}$. Passou anos a fio estudando e copiando os grandes mestres no Louvre.

47 A centralidade das noções da Arcádia foi atribuída a Virgílio por Panofsky no seu ensaio Et in Arcadia Ego: Poussin e a Tradição Elegíaca, constante em Significado nas Artes Visuais, Ed. Perspectiva, São Paulo, 1996.

48 RISHEL, Joseph J. Gauguin, Cézanne, Matisse: Visions of Arcadia, Philadelphia Museum of Art, 2012, p. 31. 49 Em 1891 Matisse matriculou-se na Academie Julian sob a tutela de William-Adolphe Bouguereau, também professor da Escola de Belas Artes de Paris, mas insatisfeito com o seu método mudou para o atelier de Moreau logo depois. 
"Uma academia sem a antiguidade é impensável”, afirma Goldstein no seu estudo das academias de arte ${ }^{50}$. 0 termo antiguidade designa, num sentido mais especifico e material, o objeto de arte grega ou romano. E foram esses objetos, as antigas estátuas romanas copiadas das gregas e remetidas para a França e o resto da Europa desde a fundação da Academia Francesa em Roma, em 1666, que constituíram os principais modelos de beleza para os estudantes da Escola de Belas Artes de Paris. Entre as estátuas mais utilizadas constavam o Apolo e o Torso de Belvedere, a Vênus de Médici, o Hércules de Farnese, o Gladiador de Borghese, entre outras. A seleção dessas estátuas copiadas do imenso acervo romano revelou, no seu próprio processo de escolha, a utilização de certos critérios de beleza formulados ao longo da história nas academias romanas. Mas foi na ascensão da Academia Francesa que esse acervo restrito de estatuária, reflexo da sua ideia de antiguidade, passou a ser definitivamente uma medida de beleza e perfeição. Copiá-las representava, mais do que uma aquisição de gosto, o aprendizado de uma linguagem da forma.
50 GOLDSTEIN, Carl. Op. Cit. p. 137

51 SHELDON, Julie and Pam Meecham. Modern Art: A critical introduction, Rootledge, NY, 2005, p. 51.

52 GOLDSTEIN. Op. Cit. P. 313 nota 41.

53 LICHTENSTEIN, Jacqueline. A Pintura - Vol. 5: Da imitação à expressão, Editora 34 Ltda, São Paulo, 2004. P. 120.

54 AVIGDOR, Arikha. J.A.D. Ingres: Fifty Life Drawings from the Musée Ingres at Montauban, the Museum of Fine Arts, Houston, 1986, p. 48.

\section{NATUREZA E IMAGINAÇÃO}

A imaginação, chamada de "rainha das faculdades" ${ }^{51}$ por Charles Baudelaire e diametralmente oposta à verdade da natureza, representou um momento singular da transição do academicismo, no seu sentido mais convencional, para $o$ modernismo na arte do princípio do século XX. A valorização da imaginação do artista na sua busca de uma iconografia pessoal, de inspiração primordialmente literária, tanto romântica quanto simbolista, significou uma mudança radical num sistema de artes que teve por séculos a natureza como sua principal referência. É importante lembrar que mesmo o Impressionismo na sua ruptura com certos fundamentos acadêmicos fez da natureza a base exemplar das suas representações.

O mesmo Baudelaire chegou a dividir os artistas em dois grupos: os realistas, que copiavam a natureza e os imaginativos, que pintavam suas próprias almas. Ingres, ao aconselhar Degas a nunca trabalhar a partir da natureza e sim a partir da memória, já antevia, coincidentemente, esse processo de mudança da arte num período posterior ao seu ${ }^{52}$. Portanto, em termos baudelairianos e sob o governo da imaginação, a natureza não passa de um dicionário e o artista que se põe a copiá-la integralmente é aquele desprovido dessa capacidade do espirito de representar imagens ${ }^{53}$.

Picasso seguiu o conselho de Ingres à risca quase nunca usou modelos vivos nas suas obras $^{54}$. Fazia pleno uso da sua imaginação e memória, complementando assim aquilo que o modelo não poderia dar, ou seja, o trabalho do gênio ou do gosto do artista. 
No caso de Picasso, cabe ainda outra menção à Baudelaire, quando este fala da imaginação como fator de integração de realidades diversas e contrárias, porém simultâneas; as anábases e as catábases do homem, a criação e a destruição, a besta e o humano, o exagero e o silêncio. Essa faculdade da imaginação, de decompor a realidade e a recompor numa nova ordem de sentido, serve como uma luva para demonstrar o método de trabalho de Picasso na elaboração das suas composições. O poder de fragmentar a realidade aparente e reapresentá-la sob uma nova lógica visual é a própria essência do cubismo. Explica, também, o envolvimento de Picasso com o ideário surrealista e a sua capacidade impar de concretizar soluções visuais para um movimento que se notabilizou, principalmente, na instância poética e literária ${ }^{55}$.

\section{A BELEZA DA LINHA}

Do ponto de vista da sua história, o arabesco decorativo e linear figurou em diversos momentos da arte ocidental, nas iluminuras célticas, no drapeado gótico, nos desenhos germânicos a pena de ave de Dürer e Burgkmair, nos desenhos das academias italianas de Disegno, na arte de William Blake e nas curvas do Art Nouveau. No seu tratado intitulado A Análise da Beleza, de 1753, William Hogarth, pintor inglês, denominou um tipo de linha, a serpentinata ou linha da graça, aquela que descreve um percurso sinuoso em torno de um elegante cone, de complexidade mutável e assimétrica, como um exemplar por excelência do belo linear. Seu livro, um importante referencial prático e teórico nas academias europeias, provavelmente não passou despercebido por Matisse, cuja lua de mel foi em Londres em 1898. É justamente essa beleza da linha, uma das características da arte clássica italiana do Renascimento, segundo Wölfflin ${ }^{56}$, que culminará numa depuração notável nos desenhos dos nus femininos de Matisse e nas mitologias de Picasso, expressões finamente lineares e gráficas da procura moderna pelas brancuras das superfícies planas do papel.

No seu aspecto formal, alguns dos desenhos lineares e rápidos produzidos por Matisse nessas sessões de "abandono" das modelos aproximam-se da musicalidade da linha de Ingres. Nas suas interrupções rítmicas dos traços, ativando o espaço em branco das superfícies anexas dos desenhos, Matisse emula os staccatos (suspensões entre notas ou breves silêncios) e legatos (ligação de notas sucessivas) dos desenhos de Ingres. Ambos os mestres estabelecem uma correspondência entre a nota musical e o traço visual no espaço plano dos seus desenhos, não esquecendo que Ingres era um músico profissional, bastante eficiente no violino ${ }^{57}$. É justamente essa qualidade imediata

55 Argan pontua com mestria a relevância de Picasso dentro do movimento surrealista ao dizer que: “E é preciso lembrar que a experiência fundamental de Picasso é a do surrealismo e que, aliás, ele representa o único êxito, o único resultado positivo ou construtivo do surrealismo". In: ARGAN, Giulio Carlo. A Arte Moderna na Europa de Hogarth a Picasso, Companhia das Letras, São Paulo, 2010, p. 562.

56 WÖLFFLIN, HEINRICH. Arte Clássica, Martins Fontes, São Paulo, 1990. Segundo Wölfflin, o estilo clássico do Renascimento é o momento do predomínio de uma concepção tátil do desenho, que enfatiza o contorno da linha e separa os objetos percebidos como valores concretos e tangíveis.

57 Julguei relevante estabelecer essa analogia da linha do desenho com a nota musical, pois as correlações mais frequentes nos textos de arte referem-se às cores. Um 
do desenho, tido como um tremor sensível da percepção e que atinge o âmago da emoção e do sentimento, que o faz se aproximar da alma (assim como fazia o canto, segundo Aristóteles) mais do que qualquer outro meio de expressão. Um exemplo distinto dessa influência da linha de Ingres nos desenhos de Matisse consta num dos quinhentos estudos preparatórios para o seu painel A Era do Ouro, mostrando um grupo de dançarinas feito na técnica de uma linha sobre papel vegetal e que antecipa a composição das duas versões da Dança de Matisse ${ }^{58}$. Não foi à toa, portanto, que o grande esteta idealista inglês Walter Pater afirmou, no final do século XIX, que "Toda arte constantemente aspira à condição da música” ${ }^{59}$ quando se referiu à união do tema e da forma na arte.

A linha pura, rigorosa, essencial, que predomina na obra gráfica de Matisse tem sua contrapartida nos seus desenhos a carvão. Nesses, que costumavam preceder os seus trabalhos lineares, a própria técnica

exemplo cabível é o depoimento do próprio Matisse quando diz que "O quadro é constituído pela combinação de superfícies diferentemente coloridas, combinação esta que resulta na criação de uma expressão. Assim como numa harmonia musical cada nota é uma parte do todo, eu também queria que cada cor tivesse um valor contributivo". In: MATISSE, Henri. Op.Cit. p. 140.

58 ARIKHA, Avigdor. Op. Cit. p. 92.

59 "All art constantly aspires towards the condition of music". In: PATER, Walter. The Renaissance: Studies in Art and Poetry. Tradução minha.

60 William Rubin destaca que o grande talento e a principal força da arte de Picasso residiam na narrativa pictórica. In: RUBIN, William. Picasso and Braque: Pioneering Cubism, The Museum of Modern Art, New York, 1989. p.16.

61 Dois bons exemplos são os retratos de Wilhelm Uhde e Ambroise Vollard, ambos datados de 1910. possibilitava uma exploração mais livre, sombreada, flexível, escultural e que permitia sucessivos apagamentos, criando efeitos de sobreposição de manchas e marcas, de sucessivos pontos de vista, alternados na realização das figuras. Eram necessárias várias sessões de poses para que o artista se sentisse esgotado pelo esforço de apreensão da modelo, segundo seu próprio depoimento, para que, só então, desse seguimento, com a mente clarificada, ao livre curso das linhas puras. $\mathrm{O}$ que Matisse atingia por certa superação psicológica nos seus nus femininos, fixando a emoção plástica nas linhas dos corpos das modelos, Picasso obtinha pelo rigor intelectivo das desconstruções nas suas mitologias ilustradas, desprovidas de qualquer conteúdo de ordem sentimental, mas com uma surpreendente precisão no uso da linha.

O ímpeto gráfico de Picasso sobrepujava sua expressão pictórica. A linha, o elemento visual mais significativo da sua arte, representou o seu envolvimento fundamental com a narrativa plástica ${ }^{60} \mathrm{e}$ o seu interesse principal, a figura humana. Era tão obcecado pela representação do homem no mundo que, até na fase mais abstrata do cubismo analítico, encontrou uma forma de fazer retratos, mostrando a sua faceta de brilhante caricaturista ${ }^{61}$. A predisposição de Picasso pelas narrativas, especialmente as sequenciais, pode ser mais bem explicada pela provável influência, durante a sua infância, das histórias populares espanholas, de caráter recitativo, as chamadas pliegos de cordel, que correspondem a nossa tradição lusitana da literatura de cordel. Além disso, havia na Barcelona do fim do século XIX uma variedade considerável de publicações, revistas e cartazes, referentes aos mais diversos assuntos, desde 
corridas de touro até os cuentos vivos, espécie de histórias em silhuetas, semelhantes aos atuais quadrinhos e ilustradas pelo grande desenhista catalão Apeles Mestres.

O envolvimento de Picasso com a gravura coincide com a abundância de ilustradores na Europa do final do século XIX e princípio do século XX, especialmente em Paris, num período de intensa alfabetização das classes média e populares da cidade luz ${ }^{62}$. Mas foi a obra de um ilustrador inglês, John Flaxman, com a sua linha pura no estilo neoclássico, que particularmente cativou a admiração de artistas do porte de Ingres, identificados com essas manifestações gráficas. Vale lembrar que o próprio Goya, patrício de Picasso, copiou gravuras de Flaxman. Mas uma das ingerências plásticas mais decisivas na sua arte gráfica mostrou ser o traçado das figuras nos vasos Áticos, do período clássico do século V A.C., que Picasso via frequentemente no Louvre. As flexíveis figuras humanas aí representadas mostravam uma invulgar animação nos seus gestos, uma notável interiorização dos sentimentos e uma utilização precisa e requintada das linhas, nessas imagens mitológicas tão características da arte utilitária grega ${ }^{63}$.

O virtuosismo do desenho de Picasso fica evidente nas séries de gravuras em metal dos anos trinta, referentes às Metamorfoses de Ovídio ${ }^{64}$ e à Suíte Vollard ${ }^{65}$, cujas qualidades gráficas remontam a certas experiências anteriores. A imaginação de Picasso era estimulada pelas analogias morfológicas já dos tempos do cubismo analítico, entre 1910 e 1914. Nesse período, juntamente com Braque, experimentou, intensa e extensamente, as ambiguidades visuais das formas. Na sua fase neoclássica dos anos vinte explorou as possibilidades da linha de contorno contínuo, aquela aprendida no seu tempo de Academia, no intuito de ombrear-se com Ingres. Num lance de singular ironia, como bem ressaltado por Argan, simulou copiar Ingres, quando na verdade as imagens eram por ele inventadas ${ }^{66}$. Com isso buscou superar o grande mestre neoclássico francês, objeto da sua profunda admiração, dentro do próprio domínio dele, ou seja, o do desenho de puro contorno.

As gravuras que ilustraram As Metamorfoses de Ovídio mostram o notório conhecimento anatômico de Picasso. A fluidez do seu traço e a precisão dos seus desenhos conformam uma estrutura orgânica, mais voltada para o ritmo linear das figuras do que para a exatidão anatômica. As sobreposições musculares nas articulações das personagens mitológicas criam situações ambíguas, quase surrealistas ${ }^{67}$, em

62 Em Paris, os principais nomes eram os de Gustave Doré e Daumier.

63 Como bem observa Stewart, os vasos gregos não eram feitos para servir de decoração em estantes e sim para serem usados como utensílios, tanto nas ocasiões festivas quanto na higiene pessoal. In: STEWART, Andrew. Art, Desire and the Body in Ancient Greece, Cambridge University Press, Califórnia, 1997, p.57. 64 As ilustrações d o poema As Metamorfoses de Ovídio decorreram de um acordo entre Picasso e o jovem editor suíço Albert Skira, em 1930. Foram elaboradas quinze ilustrações ao todo, mostrando alguns dos mitos constantes no poema.

65 A chamada Suite Vollard se refere à encomenda de gravuras feita pelo negociante de arte francês Ambroise Vollard a Picasso, constando de 100 pranchas elaboradas no período compreendido entre 1930 e 1937.

66 ARGAN, Giulio Carlo. Op. Cit. p. 586.

67 Nesse período, Picasso encontra-se no auge do seu envolvimento com o surrealismo. 
que as partes dos seus corpos se embaralham sem que se possa definir exatamente qual membro pertence a quem. A estratégia compositiva de Picasso é deslocar o sentido clássico da unidade e inteireza do corpo para o fragmento. Mediante esse expediente formal, ele suscita a participação ativa do espectador que, intrigado, busca identificar uma ordem lógica nesse verdadeiro quebra-cabeça corporal. Num segundo momento, chega-se a conclusão que os corpos se misturam, se metamorfoseiam uns nos outros, e é impossível repor a sua unidade original. Eis o aspecto simbólico e circulante dos mitos de Ovídio, associado não somente a um ou a outro personagem, mas a própria estrutura compositiva da ilustração como um todo, incluídos os chamados "espaços negativos”68.

\section{A Suite Vollard teve uma temática mais} heterogênea. As imagens alternam motivos que vão do descanso da modelo, o atelier do escultor, cenas circenses, violações sexuais, banhistas, cenas de touradas e até um personagem mitológico, o Minotauro. Obviamente que as gravuras que estampam nus

68 Picasso usa um formato levemente verticalizado, quase quadrado, e expande os grupos das figuras quase ao ponto de romper os limites dos quadros em que estão inseridas. Não há espaço para mais nada a não ser os corpos das personagens. Como uma possível alternativa ao constante no livro de Florman, propõe-se que essa expansão dos corpos nos formatos restritos seja uma provável decorrência das imagens nas métopas gregas existentes no acervo do Museu do Louvre, especialmente dos esquemas gráficos de reconstrução dos Doze Trabalhos de Héracles. A disposição das figuras nos espaços da representação é muito semelhante. Os formatos retangulares também. Florman apresenta uma influência das figuras mitológicas gravadas nos espelhos etruscos de formatos circulares e ovalados. In:

FLORMAN, Lisa. Op. Cit. pp. 17, 18 e 20.

69 MATISSE, Henri. Op. Cit. pp. 178/179. femininos deitados se aproximam mais da lírica de Matisse. Os formatos horizontais de algumas pranchas favorecem essa proximidade, especialmente aquela intitulada de Mulheres Repousando, cujos ritmos das convexidades sensuais dialogam com as das odaliscas, tanto de Matisse quanto de Ingres. As formas dos corpos apresentadas são mais compactas e a fluência dos traçados de contorno demonstra a assimilação do processo acadêmico de desenho, principalmente nas pranchas em que há o predomínio da linha pura. Essa série resultou numa das mais belas e "clássicas” de Picasso.

Vale salientar que o ponto em comum entre os desenhos de Picasso e os de Matisse foi a ênfase que ambos buscaram na brancura do papel. Ao destacarem o aspecto plano das superfícies mediante a utilização de linhas finas, promoveram, pela sua leveza visual, uma quase desmaterialização dos corpos representados. Matisse, inclusive, falou da "enternecedora brancura do papel”, das suas "alvas nuances”, do "traço comovido que modela a luz da folha branca” ${ }^{69}$. Características, aliás, presentes em alguns desenhos lineares modernistas, como nos de Jean Arp, Jules Pascin e Constantin Brancusi, todos integrantes da chamada Escola de Paris, cujas expressões maiores eram justamente Picasso e Matisse.

\section{SOLUÇÕES POSSÍVEIS}

No tocante ao envolvimento técnico com a tradição acadêmica, que Matisse e Picasso usufruíram em momentos distintos das suas carreiras, pode se dizer que foi graças a essa formação convencional que ambos puderam realizar suas obras grandiosas da pintura moderna, desenvolvendo estilos altamente 
pessoais e notadamente reformadores de muitos padrões estabelecidos. Como esperado em tais casos, em termos do processo de aprendizagem, a individuação aconteceu depois, não antes. Os desenhos mais lineares dos dois artistas refletiram a segurança adquirida na sua educação acadêmica, conforme bem comentado por Neher, no seu destacado artigo sobre Van Gogh e o problema da tradição:

"O desenho clássico, que consiste num conjunto de convenções apreendidas e que fazem perfeito sentido, em termos perceptivos, uma vez assimiladas no aparelho motor do artista, requer tanto uma maturidade crítica e inteligente quanto uma destreza física" ${ }^{70}$.

É importante ressaltar que o principal objetivo no aprendizado do desenho é o desenvolvimento da visão espacial do artista, nessa etapa tão importante da educação do olhar, e não o de produzir realismo acadêmico. A coordenação entre a mão e o olho é necessária para o domínio dos meios expressivos. Nesse aspecto, Matisse tinha plena consciência do papel e da importância da tradição na busca de uma visão de mundo unificadora e substanciada no estilo pessoal do artista. Tanto que chegou a declarar que:

"O pintor, se for sensível, não pode dispensar a contribuição da geração anterior, pois ela está dentro dele quer queira quer não. No entanto, ele precisa se desprender dela para poder oferecer, por sua vez, uma coisa nova e de inspiração fresca" ${ }^{71}$.

Em outras palavras, a importância que ele atribuía ao papel da tradição limitava-se ao período da formação do artista. Uma vez ocorrida sua individuação, ele deveria contar, sobretudo, com suas próprias forças e inventividade. A tradição pode, sim, ser um fator de liberdade e não de restrição, pois que é de dentro do seu conjunto de práticas e convenções que o novo pode emergir. A esse respeito, escreve ainda Neher:

"É possível fazer contribuições positivas, inovadoras e até revolucionárias a tradição da pintura ocidental e, simultaneamente, manter essa mesma tradição intacta. $O$ sucesso de tal empreendimento dependeria de uma profunda e precisa compreensão da tarefa" ${ }^{72}$. E cita, como exemplo, sua instigante hipótese da inseparabilidade entre o estilo e o espaço na pintura radicalmente reformadora de Cézanne, característica única na história da pintura ocidental.

No caso de Matisse, sua decisão de ser moderno circunscreveu sua atuação como um artista típico da vanguarda e ele, coerentemente, nunca se permitiu qualquer tipo de retrocesso, fosse qual fosse. Seguiu sempre o seu instinto, não importando o preço a pagar. Já Picasso, embora reconhecido como um dos grandes artistas da vanguarda de Paris, não teve pudores de abraçar as representações "neoclássicas" a partir dos anos 20, encarregando-se de desempenhar, metaforicamente falando, um tipo de arlequim ${ }^{73}$ no variado circo das representações do mundo da arte parisiense do princípio do século XX. Suas alternâncias

70 NEHER, Ross. Van Gogh and the Problem with Tradition, Arts Magazine, Janeiro 1989, p. 43.

71 MATISSE, Henri. Op. Cit. p. 222.

72 NEHER, Ross. Op. Cit. p. 47.

73 Aliás, o arlequim foi uma temática recorrente na obra de Picasso. 
metamórficas das figuras representadas e a estratégia de usar diferentes estilos de acordo com a necessidade expressiva do momento significaram a sua radical recusa de qualquer noção de progresso em arte. E o resguardaram também de ser repetitivo, visto que trabalhava quase que exclusivamente de imaginação e memória. Quanto à natureza, ele simplesmente a “incorporou”, prenunciando uma das máximas do artista norte-americano Jackson Pollock quando este, nos anos cinquenta, afirmava ser a natureza.

O afastamento de Matisse da modelo poderá ser mais bem compreendido se comparado com a transição do academicismo para o modernismo, quando o imaginário individual exacerbado do artista moderno sobrepõe-se à interpretação objetiva idealizada das formas existentes na natureza, princípio fundamental do pensamento acadêmico. Esse processo subjetivo evidencia o poder da imaginação sobre a observação. Gauguin, por sinal um dos artistas prediletos de Matisse, costumava dizer que a natureza pode muito bem ter sido o ponto de partida da sua arte, mas a sua imaginação sempre teve a última palavra. Gauguin valorizava o seu "olho interno" mais do que o seu olho físico ou "externo" ${ }^{74}$.

O abandono progressivo da modelo pode também ser interpretado como uma recapitulação das etapas do seu aprendizado do desenho, numa paulatina tomada de consciência da forma que se apresenta ao artista e aquilo que a sua técnica é capaz de figurar. Nesse embate, Matisse coteja as convenções aprendidas na

74 SHELDON, Julie and Pam Meecham, Op. cit. p. 51. 75 MATISSE, Henri. Op. Cit. p.179.
Academia e as soluções formais que surgem mediadas pela sua emoção estética. Quando esta prevalece, ocorre o abandono da modelo e se fixa a expressão no desenho, a tão almejada escrita plástica. É nesse sentido, que ele necessitava dos estudos anteriores para "liberar a graça, a naturalidade do desenho a pena" ${ }^{75}$, conforme as suas próprias palavras.

A natureza para Matisse era o catalizador da sua expressão em arte. Representava também, por assim dizer, o princípio de tudo, a sensualidade das coisas do mundo. Possuidor de uma inventividade expansiva e de pendor para o decorativo, fez do corpo da mulher e dos objetos que o cercam a razão da sua procura figurativa, seja por intermédio do desenho, da gravura, da pintura e da escultura. Foi um artista clássico na plena acepção do termo, não tanto por sua expressão plástica, mas por seu equilíbrio de espirito. Buscou, obstinadamente, a plenitude da forma e a unidade da sua obra, pela proporção e harmonia das suas partes. Dono de uma disciplina férrea, que se impôs ao longo dos anos, soube conciliar nos seus trabalhos lirismo e razão, pelo uso do seu olho "interno", ao custo de muito esforço e dedicação.

Na celebração da figura feminina sua expressão resulta de uma conjugação sutil de sentimentos e sensações interiorizadas, produtos de uma ligação vital, amorosa, sensual mesmo com as suas modelos. Nos seus desenhos o artista projetava o seu sentimento na modelo, sendo essa volúpia sublimada muito mais importante, em termos da sua expressão, do que a exatidão orgânica da obra. Dizia o próprio: "Depois de certo momento é como se fosse uma revelação, não sou mais eu. Eu não sei mais o que estou fazendo: eu me identifico com minha modelo"76. 


\section{Quadro comparativo dos desenhos lineares da figura humana entre Matisse e Picasso}

\section{Matisse Picasso}

Numa vasta carreira que abrangeu mais de sessenta anos, foi devido à sua persistência e entrega ao desenho do modelo vivo, o centro da sua realização plástica, que ele pôde oferecer ao mundo uma obra em que o corpo da mulher representou o seu encontro final com a arte.

\section{BIBLIOGRAFIA}

ARGAN, Giulio Carlo. A Arte Moderna na Europa de Hogarth a Picasso, Companhia das Letras, São Paulo, 2010.
Parte da modelo para num afastamento progressivo atingir uma essência expressiva. Eis o método Interpretação das operativo de Matisse: se formas femininas afasta da modelo, pois esta constitui um elemento perturbador do ritmo linear do desenho ${ }^{77}$.

Parte da imaginação e utiliza corpos e figuras mais ou menos estereotipadas nas narrativas mitológicas e clássicas. segundo uma rigorosa economia linear. Aspecto mais sensual.

Interpretação das formas femininas segundo o desenho de um só traço. Aspecto mais sexual.
ARNHEIM, Rudolf. Arte \& Percepção Visual, Enio Matheus Guazzelli \& Cia. Ltda. São Paulo, 1991.

AVIGDOR, Arikha. J.A.D. Ingres: Fifty Life Drawings from the Musée Ingres at Montauban, the Museum of Fine Arts, Houston, 1986.

CLARK, Kenneth. O NU, Um Estudo Sobre o Ideal em Arte, Editora Ulisseia, Lisboa, 1956.

76 NÉRET, Glles. Op. Cit. p. 169.

77 DVORAK, Frantisek. Henri Matisse - Dibujos, Ediciones Polígrafa, S.A., Barcelona, 1980, p.20. 
O desenho dos corpos mostra uma estrutura linear aberta e

Ênfase na relação do corpo feminino com o entorno decorativo da composição.

Ênfase na narrativa (dois ou mais personagens) e na ambiguidade da linha desenhada.
Caráter mais exótico e decorativo.

\section{Caráter mais} anedótico. expansiva, como que extravasando o limite do papel.

O desenho dos corpos mostra uma estrutura linear fechada e mais estável, contendo o olhar no limite da composição.
Nos retratos femininos busca a individualidade das modelos pelo uso simplificado, quase caricatural, de "signos" visuais.

Nos retratos femininos alterna representações mais líricas, tendendo ao clássico, com as quase caricaturas deformadas e surrealistas.
ELDERFIELD, John. Matisse in the Collection of the Museum of Modern Art, The Museum of Modern Art, New York, 1978.

FLORMAN, Lisa. Myth and Metamorphosis, Picasso's Classical Prints of the 1930's, The MIT Press, Cambridge, MA, 2000.

JUDRIN, Claudie. Rodin, 100 Drawings and Watercolours, Magna Books, Netherlands, 1990.

GÁLLEGO, Julián. Picasso. Suite Vollard, Fundación Juan March, Madrid, 2010.

GILOT, Françoise. Matisse e Picasso, Editora Siciliano, SP. 1990.
GOLDSTEIN, Carl. Teaching Art, Academies and Schools from Vasari to Albers, Cambridge University Press, NY, 1996.

GRAFTON, Most and Settis. The Classical Tradition, The Belknap Press of Harvard University Press, 2010.

KUCHLING, Heimo. Oskar Schlemmer Man, The MIT Press, Cambridge, Massachussets, 1971.

LICHTENSTEIN, Jacqueline. A Pintura - Vol. 5: Da imitação à expressão, Editora 34 Ltda, São Paulo, 2004. 
MATISSE, Henri. Matisse, Escritos e reflexões sobre arte, Cosac Naify, São Paulo, 2007.

NÉRET, Gilles. Matisse, Taschen, Köln, 1997.

PANOFSKY, Erwin. Significado nas Artes Visuais, Ed. Perspectiva, São Paulo, 1996.

RILKE, Rainer Maria. Auguste Rodin, Parkstone Press International, NY, 2011.

RISHEL, Joseph J. Gauguin, Cézanne, Matisse: Visions of Arcadia, Philadelphia Museum of Art, 2012.

RODIN, Auguste. Rodin on Art and Artists, Dover Publications, NY, 1983.

RUBIN, William. Picasso and Braque:

Pioneering Cubism, The Museum of Modern Art, New York, 1989.
SALZSTEIN, Sônia. Matisse: imaginação, erotismo e visão decorativa, Cosac Naify, São Paulo, 2009.

SHELDON, Julie and Pam Meecham. Modern Art: A critical introduction, Rootledge, NY, 2005.

STEIN, Gertrude. Picasso, Editora Âyiné, BH, 2016. STEWART, Andrew. Art, Desire and the Body in Ancient Greece, Cambridge University Press, Califórnia, 1997.

WARNCKE, Carsten-Peter. Picasso, Taschen, Köln, 2002.

WÖLFFLIN, HEINRICH. Arte Clássica, Martins Fontes, São Paulo, 1990. 